\title{
Diversity, geographical distribution, and prevalence of Entamoeba spp. in Brazil: a systematic review and meta-analysis
}

Andernice dos Santos Zanetti ${ }^{1}$, Antonio Francisco Malheiros ${ }^{1}$, Tatiane Amorim de Matos ${ }^{1}$, Carolina dos Santos ${ }^{1}$, Paula Franciene Battaglini ${ }^{2}$, Luciana Melhorança Moreira ${ }^{3}$, Larissa Maria Scalon Lemos ${ }^{4}$, Solange Kimie Ikeda Castrillon ${ }^{1}$, Denise da Costa Boamorte Cortela ${ }^{5}$, Eliane Ignotti ${ }^{1}$, and Omar Ariel Espinosa ${ }^{6, *}$

${ }^{1}$ Post-Graduation Program in Environmental Science, Faculty of Agricultural and Biological Sciences, State University of Mato Grosso (UNEMAT), Tancredo Neves Ave., 1095 - Cavalhada II, Caceres, 78217-042 Mato Grosso, Brazil

${ }^{2}$ Residency in Infectious Diseases, Júlio Miller University Hospital, Federal University of Mato Grosso, Luis Philippe Pereira Leite St., Alvorada, Cuiabá, 78048-902 Mato Grosso, Brazil

${ }^{3}$ Faculty of Agricultural and Biological Sciences, State University of Mato Grosso (UNEMAT), Tancredo Neves Ave., 1095 - Cavalhada II, 78217-042 Caceres, Mato Grosso, Brazil

${ }^{4}$ Department of Nursing, Faculty of Health Sciences, State University of Mato Grosso (UNEMAT), Tancredo Neves Ave., 1095 - Cavalhada II, Caceres, 78217-042 Mato Grosso, Brazil

5 Department of Medicine, Faculty of Health Sciences, State University of Mato Grosso (UNEMAT), Tancredo Neves Ave., 1095 - Cavalhada II, 78217-042 Caceres, Mato Grosso, Brazil

${ }^{6}$ Faculty Estacio of Pantanal (Estacio FAPAN), São Luís, 2522 St - Cidade Nova, Caceres, 78201-000 Mato Grosso, Brazil

Received 29 December 2020, Accepted 11 March 2021, Published online 30 March 2021

\begin{abstract}
The genus Entamoeba includes a variety of widely distributed species adapted to live in the digestive tracts of humans and a large variety of animals of different classes. The objective of this study was to investigate the prevalence, distribution, and molecular epidemiology of Entamoeba spp. in different classes of hosts in Brazil. Studies that analyzed hosts from several classes, including humans and domestic, wild, or captive animals, were considered. The pooled prevalence of Entamoeba spp. was calculated using the random-effects model. A total of 166 studies on humans and 16 on animals were included. The prevalence of Entamoeba spp. in the Brazilian population was $22 \%$ (95\% CI: 21-24). The state with the highest prevalence was Paraiba with $72 \%$, followed by Federal District with 53\%, and Rondonia with 50\%. In immunocompromized patients, the prevalence was 18\%, and cancer $(36 \%)$ was the most prevalent cause of immunosuppression. The prevalence of Entamoeba spp. in animal hosts was $12 \%$ (95\% CI: 7-17). Captive wild animals and domestic farm animals showed the highest prevalence, with $16 \%$ and $15 \%$, respectively. The species found more often were E. coli $(86.5 \%)$, E. dispar $(7.9 \%)$, and E. histolytica (3.1\%). In conclusion, a high prevalence (22\%) of Entamoeba spp. was found in the Brazilian population, with a prevalence of up to $50 \%$ mainly in the northern, northeastern, and central-western regions. The pathogenic species E. histolytica is distributed in most Brazilian regions, with significant prevalence percentages. Among animals, unidentified Entamoeba species were most prevalent in mammals.
\end{abstract}

Key words: Parasitic disease, Amebiasis, Diarrhea, Zoonoses, Protozoan.

Résumé - Diversité, répartition géographique et prévalence d'Entamoeba spp. au Brésil : revue systématique et méta-analyse. Le genre Entamoeba comprend une variété d'espèces largement distribuées, adaptées à vivre dans le tube digestif des humains et une grande variété d'animaux de différentes classes. L'objectif de cette étude était d'étudier la prévalence, la distribution et l'épidémiologie moléculaire d'Entamoeba spp. dans différentes classes d'hôtes au Brésil. Les études qui ont analysé les hôtes de plusieurs classes, y compris les humains et les animaux domestiques, sauvages ou captifs, ont été prises en compte. La prévalence combinée d'Entamoeba spp. a été calculée à l'aide du modèle à effets aléatoires. Au total, 166 études sur l'homme et 16 sur les animaux ont été incluses. La prévalence d'Entamoeba spp. dans la population brésilienne était de $22 \%$ (IC à $95 \%: 21-24$ ). L'état avec la prévalence la plus élevée était Paraiba avec $72 \%$, suivi du District fédéral avec $53 \%$ et Rondonia avec $50 \%$. Chez les patients immunodéprimés, la prévalence était de $18 \%$ et le cancer (36\%) était la cause la plus fréquente d'immunosuppression. La prévalence d'Entamoeba spp. chez les hôtes animaux était de $12 \%$ (IC à $95 \%: 7-17)$. Les animaux sauvages en captivité et les animaux domestiques d'élevage ont affiché la prévalence la

*Corresponding author: omar. espinosa@fapan. edu.br

This is an Open Access article distributed under the terms of the Creative Commons Attribution License (https://creativecommons.org/licenses/by/4.0), which permits unrestricted use, distribution, and reproduction in any medium, provided the original work is properly cited. 
plus élevée, avec respectivement $16 \%$ et $15 \%$. Les espèces trouvées le plus souvent étaient E. coli (86,5\%), E. dispar $(7,9 \%)$ et $E$. histolytica $(3,1 \%)$. En conclusion, une prévalence élevée $(22 \%)$ d'Entamoeba spp. a été trouvée dans la population brésilienne, allant jusqu'à $50 \%$ principalement dans les régions du nord, du nord-est et du centre-ouest. L'espèce pathogène $E$. histolytica est répartie dans la plupart des régions du Brésil, avec des pourcentages de prévalence importants. Parmi les animaux, les espèces d'Entamoeba non identifiées étaient les plus répandues chez les mammifères.

\section{Introduction}

The genus Entamoeba includes a variety of anaerobic, unicellular, and monoxenic protozoan species adapted to live as parasites or commensals in the digestive tracts of humans and a large variety of animals of different classes $[5,7,64,110$, $112,205,206]$.

The main species of this genus that parasitize humans are E. histolytica, E. dispar, E. moshkovskii, E. coli, E. polecki, E. bangladeshi, and E. hartmanni [84, 124, 151, 174]. Morphologically, the species E. histolytica, E. dispar, and E. moshkovskii are considered identical, but only E. histolytica is the causative agent of amebiasis, a gastrointestinal disease that commonly occurs worldwide; amebiasis is considered endemic in tropical regions and is associated with inadequate socioeconomic and sanitary conditions [8, 166, 216]. Entamoeba histolytica shows several degrees of virulence and is capable of invading a wide variety of tissues in the host, including those of the colon and liver, and more rarely the lung, skin, urogenital tract, brain, and spleen. This invasive feature separates it from the other species [70]. It is estimated that amebiasis accounts for 55500 all-age deaths and causes disability-adjusted life years at 2.237 million [211].

In contrast, $E$. dispar can cause focal intestinal lesions in laboratory animals [133]. However, in humans, it is considered a stable commensal with no virulent characteristics, producing an asymptomatic carrier state and being generally much more prevalent worldwide than $E$. histolytica $[64,124]$. On the other hand, the idea that E. dispar is a simple commensal parasite is under discussion, and some authors discuss the importance of this species in damage of the intestine and liver [73].

Globally, the overall prevalence of Entamoeba spp. in humans is 3.5\%. Entamoeba histolytica and E. dispar account for $81.7 \%$ of this global prevalence in documented infections. The comparison of prevalence by regions showed differences in prevalence between Australia (1.7\%) and North America (21.6\%) [64].

Regarding zoonotic potential, research on E. histolytica, E. dispar, E. hartmanni, E. coli, E. moshkovskii, and E. polecki is remarkably important because of previous reports on these species in both humans and different species of animals worldwide $[76,110,152,165,206]$. Furthermore, regarding pathogenic potential, some of these species can cause diarrhea and other symptomatic presentations in non-human primates [165].

The Entamoeba spp. have a variety of vertebrate hosts: E. moshkovskii is found in cattle, elephants, and reptiles [94, 110]; E. coli and E. hartmanni are found in non-human primates [26, 57, 113, 220]; and finally, some studies suggest that different subtypes of $E$. polecki, infect human, non-human primates, pigs and ostriches [41, 59, 76, 84, 112].

In Brazil, several studies based on microscopic examination have investigated the prevalence of amebiasis in different population groups, but discriminatory studies between species (using molecular methods) are relatively scarce and mainly address different animal hosts. Although there are data on the prevalence of Entamoeba spp. in some regions, there is no aggregate analysis of the prevalence and distribution of species of this protozoan by geographic area, sex, age group, and host type in Brazil. Therefore, the objective of this systematic review and meta-analysis was to determine the prevalence and distribution of different species of Entamoeba in several host classes in Brazil.

\section{Materials and methods}

The protocol of this systematic review was registered in the International Prospective Register of Systematic Reviews (PROSPERO 2019: CRD42020167222) before its implementation. The protocol and final report were developed according to the Cochrane Handbook for Systematic Reviews of Interventions [105].

\section{The review question}

What is the prevalence and geographical distribution of Entamoeba spp. in different host species in Brazil?

\section{Inclusion and exclusion criteria}

This review included studies on various hosts (humans and domestic, wild, or captive animals) of different classes to determine the prevalence and genetic identification of Entamoeba spp. in Brazil through coprological analyses and molecular techniques.

Studies analyzing fecal samples of humans and domestic, wild, or captive animals that did not report percentages of samples positive for Entamoeba spp. were excluded.

\section{Types of studies}

This review included cross-sectional epidemiological studies assessing the prevalence of Entamoeba spp. in humans and wild, captive, and domestic animals.

\section{Search strategy}

An initial search limited to MEDLINE was conducted using MeSH index terms and related keywords. Subsequently, the words contained in the title, abstract, and index terms used to describe the articles were analyzed. A second search using all identified keywords and index terms was performed using all included databases. As a source of gray literature, a search 
was conducted in the reference lists of dissertations and theses that evaluated the prevalence of protozoan intestinal parasites. Because this search was limited to Brazil, it was limited to studies in the English, Spanish, and Portuguese languages. This search had no start date limitation but was completed in November 2020.

The studies were searched in the following databases: Spanish Bibliographic Index of Health Sciences (IBECS), Latin American and Caribbean Literature in Health Sciences (LILACS), Virtual Health Library (BVS), US National Library of Medicine bibliographic database (Medline), Elsevier database EMBASE, Cumulative Index to Nursing and Allied Health Literature (CINAHL), Web of Science, Cochrane Library, and National Institute of Health and Clinical Excellence (NICE). The MeSH index terms searched were Entamoeba and Brazil. The keywords Brasil and Endamoeba were also included in the search. The MeSH terms and keywords were combined via the boolean operators "AND" and/or "OR" to compose the search strings.

\section{Assessment of methodological quality}

The articles selected for data retrieval were analyzed by two independent reviewers to evaluate the methodological validity of each text before inclusion in this review. The quality of the publications included was evaluated based on the Grading of Recommendations Assessment, Development, and Evaluation (GRADE) criteria. Studies received one point for not presenting a study design or execution limitations (risk of bias), inconsistency of results, indirectness of evidence, imprecision, and publication bias. A score of 4-5 points was considered high quality, 3 as moderate quality, and $0-2$ as low quality.

\section{Data extraction}

The selected texts were evaluated by two independent reviewers for validity before inclusion; discrepancies were resolved by an independent reviewer. The data were entered into the Review Manager (RevMan 5.3) [168] software for analysis. A data extraction table was used to evaluate the quality of demographic data, study location, sample size, number of cases, number of positive cases, and diagnostic test.

\section{Data summary}

The random-effects meta-analysis model was used to analyze the overall combined prevalence of Entamoeba spp. in humans and animals. The heterogeneity among studies was evaluated using I2-statistic, which shows the percentage of variation among studies. These analyses were performed using the Stata software, version 12.

\section{Results}

Our systematic literature search yielded 1694 manuscripts using the established search strategies. As per the eligibility criteria (after exclusion of duplicate texts and articles related to other topics and exclusion of text based on review criteria or owing to method quality), 182 studies were selected for analysis (Table 1) [2-4, 6, 7, 9-25, 27-37, 39, 40, 42-45, 47-56, 58, 60-63, 65-69, 71, 72, 74, 75, 77-83, 85-93, 95-104, 106-109, $111,114-123,125-130,132,135,136,138-140,142-146$, 148-150, 153-164, 167, 169-173, 175-192, 194-204, 207210, 212-215, 217-219]. Of these studies, 166 evaluated the prevalence of Entamoeba spp. in human fecal samples from different Brazilian states during different periods; the remaining 16 studies analyzed the prevalence of Entamoeba spp. parasites in different wild, captive, and domestic animals. Of the 182 studies included, 9 identified the species of the genus Entamoeba by molecular characterization, 17 by serology, and 2 by isoenzyme analysis. The results of this search strategy are presented in a Preferred Reporting Items for Systematic Reviews and Meta-Analyzes (PRISMA) flowchart (Fig. 1). Data were extracted according to the PRISMA Statement [141].

Regarding the methodological quality, according to the GRADE criteria used, all 166 studies evaluating the prevalence of Entamoeba spp. in different Brazilian populations as well as the 16 studies evaluating its prevalence in different animal host species presented a high methodological quality, all with a score of 5 .

\section{Entamoeba spp. in the Brazilian population}

Overall, the 166 studies on human samples included 268,465 coprological tests and 114 from the oral cavity, including samples from 24 Brazilian states and the Federal District. The only states not analyzed were Roraima and Tocantins, both in the northern region. Test distribution by state showed that 10 studies were performed in Bahia (representing $40.2 \%$ of the analyzed samples), 4 in Piaui (15.1\%), 11 in Rio Grande do Sul (11.0\%), 25 in Minas Gerais (6.1\%), 10 in Parana (4.0\%), 22 in Sao Paulo (3.3\%), 11 in Rio de Janeiro (2.7\%), 15 in Amazonas (2.2\%), 6 in Pernambuco (1.9\%), 6 in Santa Catarina (1.3\%), 5 in Ceara (0.8\%), 5 in Paraiba (0.8\%), 5 in Para (0.6\%), 7 in Mato Grosso do Sul (0.6\%), 3 in Sergipe $(0.5 \%), 8$ in Mato Grosso $(0.4 \%)$, and 4 in Espirito Santo $(0.2 \%)$. Two studies were conducted in the states of Maranhao (1.6\% of the included samples) and Alagoas (1.0\%). Only one study was conducted in Amapa (3.7\%), Rio Grande do Norte $(1.3 \%)$, Goias $(0.4 \%)$, Acre $(0.2 \%)$, Rondonia $(0.1 \%)$, and the Federal District $(0.03 \%)$.

Of the 166 studies analyzed, only 19 distributed patient samples by sex, totaling 56,442 samples, of which $65 \%$ were female and 35\% male, with $1992(3.5 \%)$ positive samples. Of the positive samples, $1082(54.3 \%)$ were from females and $910(45.7 \%)$ from males.

Fifty-six studies distributed the samples by age group, totaling 35,411 samples. Of these samples, 26,143 (73.8\%) were from children aged 0-9 years; 5971 (16.8\%) from aged 10-19 years, and 3297 (9.4\%) from adults aged over 19 years. Of these samples, $5684(16.1 \%)$ were positive for Entamoeba spp., with $4133(72.7 \%)$ from children aged 0-9 years, 609 (10.8\%) from 10-19 years, and 942 (16.5\%) from adults over 19 years.

Regarding the status of the immune system, 266,794 $(99.3 \%)$ of the samples were from patients with no previously 
Table 1. A summary of the included studies.

\begin{tabular}{|c|c|c|c|c|c|c|}
\hline No. & Region & City - State & Total $N$ & $\begin{array}{c}\text { Prevalence } \\
(\%)\end{array}$ & $\begin{array}{l}\text { Diagnostic } \\
\text { method }\end{array}$ & Author/year \\
\hline \multicolumn{7}{|c|}{ Human host } \\
\hline 1 & Midwest & Caceres - MT & 53 & 9.4 & $\mathrm{C}$ & Alencar et al. [7] \\
\hline 2 & Midwest & Campo Novo do Parecis - MT & 43 & 37.2 & $\mathrm{C}$ & Zenazokenae et al. [219] \\
\hline 3 & Midwest & Caceres - MT & 183 & 36.6 & $\mathrm{C}$ & Silva et al. [196] \\
\hline 4 & Midwest & Rondonopolis - MT & 215 & 11.5 & $\mathrm{C}$ & Luz et al. [125] \\
\hline 5 & Midwest & Parque do Xingu - MT & 304 & 52.9 & $\mathrm{C}$ & Escobar-Pardo et al. [77] \\
\hline 6 & Midwest & MT & 173 & 16.8 & $\mathrm{C}$ & Coimbra Jr and Santos [60] \\
\hline 7 & Midwest & Parque Xingu - MT & 62 & 75.8 & $\mathrm{C}$ & Ferreira et al. [87] \\
\hline 8 & Midwest & Mirassol D'Oeste - MT & 149 & 38.2 & $\mathrm{C}$ & Latorraca et al. [118] \\
\hline 9 & Midwest & Corumba - MS & 200 & 52.0 & $\mathrm{C}$ & Silva et al. [198] \\
\hline 10 & Midwest & Corumba - MS & 196 & 55.1 & $\mathrm{C}$ & Silva et al. [197] \\
\hline 11 & Midwest & Campo Grande - MS & 510 & 4.6 & $\mathrm{C}$ & Curval et al. [65] \\
\hline 12 & Midwest & Campo Grande - MS & 66 & 25.7 & $\mathrm{C}$ & Higa Júnior et al. [104] \\
\hline 13 & Midwest & MS & 103 & 43.7 & $\mathrm{C}$ & Neres-Norberg et al. [150] \\
\hline 14 & Midwest & Bonito - MS & 115 & 23.5 & $\mathrm{C}$ & Gomes et al. [97] \\
\hline 15 & Midwest & Sidrolandia - MS & 313 & 64.8 & $\mathrm{C}$ & Aguiar et al. [4] \\
\hline 16 & Midwest & $\mathrm{DF}$ & 75 & 53.3 & $\mathrm{C}$ & Pereira et al. [157] \\
\hline 17 & Midwest & Cumari - GO & 1029 & 2.7 & $\mathrm{C}$ & Borges et al. [33] \\
\hline 18 & South & Moreira Sales - PR & 42 & 4.8 & $\mathrm{C}$ & Barbosa and Pavanelli [20] \\
\hline 19 & South & Maringa - PR & 150 & 16.0 & $\mathrm{C}$ & Colli et al. [61] \\
\hline 20 & South & Campo Mourao - PR & 5219 & 7.2 & $\mathrm{C}$ & Mortean et al. [144] \\
\hline 21 & South & Maria Helena - PR & 431 & 6.5 & $\mathrm{C}$ & Santos and Merlini [177] \\
\hline 22 & South & Cascavel - PR & 343 & 17.8 & $\mathrm{C}$ & Takizawa et al. [207] \\
\hline 23 & South & Ubirata - PR & 86 & 4.6 & $\mathrm{C}$ & Falavigna et al. [79] \\
\hline 24 & South & Campo Mourao - PR & 86 & 4.6 & $\mathrm{C}$ & Kulik et al. [117] \\
\hline 25 & South & Jataizinho - PR & 264 & 26.9 & $\mathrm{C}$ & Lopes et al. [122] \\
\hline 26 & South & Pitanga - PR & 181 & 20.9 & $\mathrm{C}$ & $\begin{array}{c}\text { Nascimento and Moitinho } \\
\text { [149] }\end{array}$ \\
\hline 27 & South & Maringa - PR & 369 & 5.9 & $\mathrm{C}$ & Guilherme et al. [101] \\
\hline 28 & South & Porto Alegre - PR & 17,951 & 15.1 & $\mathrm{C}$ & De Carli et al. [69] \\
\hline 29 & South & Pelotas - RS & 73 & 35.6 & $\mathrm{C}$ & Jeske et al. [111] \\
\hline 30 & South & Ipe - RS & 124 & 4.0 & $\mathrm{C}$ & Zanotto et al. [218] \\
\hline 31 & South & Palmeiras das Missoes - RS & 209 & 20.6 & $\mathrm{C}$ & Nagel et al. [148] \\
\hline 32 & South & Caxias do Sul - RS & 257 & 1.5 & $\mathrm{C}$ & Camello et al. [44] \\
\hline 33 & South & Caxias do Sul - RS & 331 & 3.3 & $\mathrm{C}$ & Porto et al. [162] \\
\hline 34 & South & Flores da Cunha - RS & 341 & 3.2 & $\mathrm{C}$ & Cavagnolli et al. [53] \\
\hline 35 & South & Rio Grande - RS & 144 & 28.5 & $\mathrm{C}$ & Mata-Santos et al. [136] \\
\hline 36 & South & Porto Alegre - RS & 146 & 10.3 & $\mathrm{C}$ & Silva et al. [192] \\
\hline 37 & South & Caxias do Sul - RS & 9787 & 14.6 & $\mathrm{C}$ & Basso et al. [22] \\
\hline 38 & South & Porto Alegre - RS & 181 & 14.9 & $\mathrm{C}$ & Bencke et al. [24] \\
\hline 39 & South & Campos Novos - SC & 109 & 13.7 & $\mathrm{C}$ & Biolchi et al. [28] \\
\hline 40 & South & Florianopolis - SC & 3126 & 3.5 & $\mathrm{C}$ & Bueno et al. [40] \\
\hline 41 & South & Florianopolis - SC & 57 & 31.6 & $\mathrm{C}$ & Santos et al. [180] \\
\hline 42 & South & Blumenau - SC & 53 & 18.9 & $\mathrm{C}$ & Andrade et al. [11] \\
\hline 43 & South & Criciuma - SC & 94 & 56.4 & $\mathrm{E}$ & Schnack et al. [185] \\
\hline 44 & South & Florianopolis - SC & 43 & 4.6 & $\mathrm{C}$ & Korzeniowski et al. [116] \\
\hline 45 & Northeast & Teresina - PI & 39,539 & 8.4 & $\mathrm{C}$ & Ibiapina et al. [108] \\
\hline 46 & Northeast & Burti dos Lopes - PI & 511 & 8.4 & $\mathrm{C}$ & Sousa et al. [201] \\
\hline 47 & Northeast & Parnaiba - PI & 251 & 29.9 & $\mathrm{C}$ & Fernandes et al. [85] \\
\hline 48 & Northeast & Sao Raimundo Nonato - PI & 265 & 42.6 & $\mathrm{C}$ & Alves et al. [10] \\
\hline 49 & Northeast & Santa Cruz - RN & 3480 & 2.3 & $\mathrm{C}$ & Lima et al. [121] \\
\hline 50 & Northeast & Aracaju - SE & 476 & 31.3 & $\mathrm{C}$ & Oliveira et al. [155] \\
\hline 51 & Northeast & Aracaju - SE & 500 & 32.6 & $\mathrm{C}$ & Rollemberg et al. [172] \\
\hline 52 & Northeast & Aracaju - SE & 298 & 14.1 & $\mathrm{C}$ and $\mathrm{E}$ & Lawson et al. [119] \\
\hline 53 & Northeast & Santo Antonio de Jesus - BA & 144 & 45.8 & $\mathrm{C}$ & Reis et al. [167] \\
\hline 54 & Northeast & Salvador - BA & 48,028 & 0.5 & $\mathrm{C}$ and $\mathrm{M}$ & Soares et al. [200] \\
\hline 55 & Northeast & Santo Antonio de Jesus - BA & 144 & 45.8 & $\mathrm{C}$ & Andrade et al. [12] \\
\hline 56 & Northeast & Aiquara - BA & 236 & 15.7 & $\mathrm{C}$ & Santos et al. [183] \\
\hline 57 & Northeast & Feira de Santana - BA & 349 & 50.1 & $\mathrm{C}$ & Almeida et al. [9] \\
\hline 58 & Northeast & Ilheus - BA & 97 & 49.5 & $\mathrm{C}$ and $\mathrm{E}$ & Santos et al. [181] \\
\hline
\end{tabular}


Table 1. (Continued)

\begin{tabular}{|c|c|c|c|c|c|c|}
\hline No. & Region & City - State & Total $N$ & $\begin{array}{c}\text { Prevalence } \\
(\%)\end{array}$ & $\begin{array}{c}\text { Diagnostic } \\
\text { method }\end{array}$ & Author/year \\
\hline 59 & Northeast & Salvador - BA & 200 & 65.0 & $\mathrm{C}$ & Seixas et al. [186] \\
\hline 60 & Northeast & Salvador - BA & 52,704 & 3.4 & $\mathrm{C}$ and $\mathrm{M}$ & Santos et al. [178] \\
\hline 61 & Northeast & Salvador - BA & 5624 & 15.6 & $\mathrm{C}$ & Santos et al. [176] \\
\hline 62 & Northeast & Ipira - BA & 410 & 12.2 & $\mathrm{C}$ & Santos-Junior et al. [184] \\
\hline 63 & Northeast & Cuite - PB & 45 & 40.0 & $\mathrm{C}$ & Bezerra et al. [27] \\
\hline 64 & Northeast & Joao Pessoa - PB & 150 & 18.6 & $\mathrm{C}$ & Monteiro et al. [143] \\
\hline 65 & Northeast & Campina Grande - PB & 1195 & 69.0 & $\mathrm{C}$ and $\mathrm{E}$ & Silva et al. [195] \\
\hline 66 & Northeast & Joao Pessoa - PB & 67 & 28.3 & $\mathrm{C}$ & Magalhães et al. [129] \\
\hline 67 & Northeast & Campina Grande - PB & 742 & 93.1 & $\mathrm{C}$ & Silva et al. [188] \\
\hline 68 & Northeast & Russas - CE & 213 & 21.6 & $\mathrm{C}$ and $\mathrm{M}$ & Calegar et al. [43] \\
\hline 69 & Northeast & Fortaleza - CE & 582 & 29.4 & $\mathrm{C}$ & Bachur et al. [15] \\
\hline 70 & Northeast & Fortaleza - CE & 735 & 38.3 & $\mathrm{C}$ and $\mathrm{E}$ & Braga et al. [36] \\
\hline 71 & Northeast & Fortaleza - CE & 161 & 20.5 & $\mathrm{E}$ & Braga et al. [35] \\
\hline 72 & Northeast & Fortaleza - CE & 564 & 36.2 & $\mathrm{C}$ and $\mathrm{E}$ & Braga et al. [34] \\
\hline 73 & Northeast & Maceio - AL & 1003 & 6.4 & $\mathrm{C}$ and $\mathrm{M}$ & Santos et al. [182] \\
\hline 74 & Northeast & Maceio - AL & 1798 & 3.8 & $\mathrm{C}$ and $\mathrm{E}$ & Duarte et al. [74] \\
\hline 75 & Northeast & Recife - PE & 213 & 4.7 & $\mathrm{C}$ and $\mathrm{E}$ & Dourado et al. [72] \\
\hline 76 & Northeast & Recife e Macaparana - PE & 1783 & 5.8 & $\mathrm{C}$ and $\mathrm{M}$ & Pinheiro et al. [159] \\
\hline 77 & Northeast & Macaparana - PE & 1437 & 2.6 & $\mathrm{C}$ and $\mathrm{M}$ & Pinheiro et al. [158] \\
\hline 78 & Northeast & Recife, Palmares e Bodoco - PE & 633 & 28.3 & $\mathrm{C}, \mathrm{Z}$ and $\mathrm{E}$ & Aca et al. [3] \\
\hline 79 & Northeast & Sao Lourenço da Mata - PE & 485 & 41.2 & $\mathrm{C}$ and $\mathrm{E}$ & Gonçalves et al. [98] \\
\hline 80 & Northeast & Recife - PE & 459 & 50.9 & E & Okazaki et al. [153] \\
\hline 81 & Northeast & Chapadinha - MA & 3933 & 26.9 & $\mathrm{C}$ & Silva et al. [190] \\
\hline 82 & Northeast, North & Timo - MA, Macapa - AP & 10,260 & 3.8 & $\mathrm{C}$ & Ferraz et al. [86] \\
\hline 83 & North & Belem - PA & 320 & 3.7 & $\mathrm{C}$ & Carvalho et al. [50] \\
\hline 84 & North & Santarem - PA & 367 & 34.3 & $\mathrm{C}$ & Banhos et al. [16] \\
\hline 85 & North & Belem - PA & 334 & 28.4 & $\mathrm{C}$ and $\mathrm{E}$ & Silva et al. [187] \\
\hline 86 & North & Belem - PA & 438 & 28.9 & E & Póvoa et al. [163] \\
\hline 87 & North & $\mathrm{PA}$ & 300 & 57.6 & $\mathrm{C}$ & Miranda et al. [140] \\
\hline 88 & North & Presidente Figueiredo - AM & 143 & 4.2 & $\mathrm{C}$ & Gonçalves et al. [99] \\
\hline 89 & North & Coari - AM & 65 & 9.2 & $\mathrm{C}$ & Silva et al. [194] \\
\hline 90 & North & Santa Izabel do Rio Negro - AM & 463 & 25.3 & $\mathrm{C}$ & Valverde et al. [215] \\
\hline 91 & North & Manaus - AM & 400 & 40.5 & $\mathrm{C}$ & Oliveira et al. [154] \\
\hline 92 & North & Iauarete - AM & 333 & 31.2 & $\mathrm{C}$ & Boia et al. [32] \\
\hline 93 & North & Manaus - AM & 451 & 23.9 & $\mathrm{C}$ & Maia et al. [130] \\
\hline 94 & North & Coari - AM & 211 & 29.4 & $\mathrm{C}$ & Monteiro et al. [142] \\
\hline 95 & North & Coari - AM & 123 & 21.1 & $\mathrm{C}$ & Silva et al. [189] \\
\hline 96 & North & Sao Gabriel da Cachoeira - AM & 895 & 29.9 & $\mathrm{C}$ & Rios et al. [170] \\
\hline 97 & North & Santa Izabel do Rio Negro - AM & 308 & 71.7 & $\mathrm{C}$ & Boia et al. [31] \\
\hline 98 & North & Eirunepe - AM & 413 & 38.2 & $\mathrm{C}$ & Araújo and Fernandez [13] \\
\hline 99 & North & Manaus - AM & 1585 & 37.3 & $\mathrm{C}$ and $\mathrm{E}$ & Benetton et al. [25] \\
\hline 100 & North & Nova Olinda do Norte - AM & 81 & 23.4 & $\mathrm{C}$ & Hurtado-Guerrero et al. [106] \\
\hline 101 & North & Novo Airao - AM & 316 & 29.1 & $\mathrm{C}$ & Boia et al. [30] \\
\hline 102 & North & Manaus - AM & 110 & 9.1 & $\mathrm{C}$ & Giugliano et al. [96] \\
\hline 103 & North & Ariquemes e Monte Negro - RO & 216 & 50.4 & $\mathrm{C}$ and $\mathrm{E}$ & Santos et al. [179] \\
\hline 104 & North & Acrelandia - AC & 429 & 25.6 & $\mathrm{C}$ & Souza et al. [202] \\
\hline 105 & Southeast & Diamantina - MG & 66 & 18.2 & $\mathrm{C}$ & Eustachio et al. [78] \\
\hline 106 & Southeast & Belo Horizonte - MG & 6289 & 6.5 & $\mathrm{C}$ and $\mathrm{M}$ & Costa et al. [62] \\
\hline 107 & Southeast & Viçosa - MG & 419 & 32.9 & $\mathrm{C}$ & Iasbik et al. [107] \\
\hline 108 & Southeast & Alfenas - MG & 277 & 2.5 & $\mathrm{C}$ & Felizardo et al. [83] \\
\hline 109 & Southeast & Ituiutaba - MG & 140 & 22.1 & $\mathrm{C}$ & Moura et al. [146] \\
\hline 110 & Southeast & Sete Lagoas - MG & 26 & 30.8 & $\mathrm{C}$ & Pires et al. [160] \\
\hline 111 & Southeast & Uberaba - MG & 1323 & 6.4 & $\mathrm{C}$ & Cabrine-Santos et al. [42] \\
\hline 112 & Southeast & Caldas - MG & 60 & 66.6 & $\ldots$ & Simões et al. [199] \\
\hline 113 & Southeast & Divinopolis - MG & 1403 & 5.7 & $\mathrm{C}$ and $\mathrm{E}$ & Pereira et al. [156] \\
\hline 114 & Southeast & MG & 409 & 89.7 & $\mathrm{C}$ & Assis et al. [14] \\
\hline 115 & Southeast & Uberaba - MG & 82 & 63.4 & M & Cembranelli et al. [54] \\
\hline 116 & Southeast & Ouro verde de minas - MG & 315 & 28.2 & $\mathrm{C}$ & Carvalho et al. [49] \\
\hline 117 & Southeast & Uberlandia - MG & 110 & 17.3 & $\mathrm{C}$ & Ferreira-Filho et al. [89] \\
\hline 118 & Southeast & Viçosa - MG & 246 & 4.1 & $\mathrm{C}$ & Einloft et al. [75] \\
\hline
\end{tabular}


Table 1. (Continued)

\begin{tabular}{|c|c|c|c|c|c|c|}
\hline No. & Region & City - State & Total $N$ & $\begin{array}{l}\text { Prevalence } \\
(\%)\end{array}$ & $\begin{array}{c}\text { Diagnostic } \\
\text { method }\end{array}$ & Author/year \\
\hline 119 & Southeast & Pato de Minas - MG & 161 & 16.1 & $\mathrm{C}$ & Silva and Silva [191] \\
\hline 120 & Southeast & Berilo - MG & 149 & 24.8 & $\mathrm{C}$ & Martins et al. [135] \\
\hline 121 & Southeast & Vespasiano - MG & 176 & 16.5 & $\mathrm{C}$ & Barçante et al. [21] \\
\hline 122 & Southeast & Uberlandia - MG & 160 & 23.1 & $\mathrm{C}$ & Machado et al. [127] \\
\hline 123 & Southeast & Abadia dos Dourados - MG & 376 & 20.5 & $\mathrm{C}$ & Machado et al. [128] \\
\hline 124 & Southeast & Belo Horizonte - MG & 472 & 14.6 & $\mathrm{C}$ & Menezes et al. [138] \\
\hline 125 & Southeast & Vespasiano - MG & 537 & 6.3 & $\mathrm{C}$ & Santos et al. [175] \\
\hline 126 & Southeast & Bambui - MG & 2811 & 7.4 & $\mathrm{C}$ & Rocha et al. [171] \\
\hline 127 & Southeast & Uberlandia - MG & 264 & 1.5 & $\mathrm{C}$ & Rezende et al. [169] \\
\hline 128 & Southeast & Uberlandia - MG & 104 & 24.0 & $\mathrm{C}$ & Costa-Cruz et al. [63] \\
\hline 129 & Southeast & Uberlandia - MG & 100 & 62.0 & $\mathrm{C}$ & Favoreto Jr and Machado [82] \\
\hline 130 & Southeast & Sao Mateus - ES & 50 & 36.0 & $\mathrm{C}$ & Albuquerque and Souza [6] \\
\hline 131 & Southeast & Sao Matheus - ES & 42 & 19.0 & $\mathrm{C}$ & Brauer et al. [39] \\
\hline 132 & Southeast & Sao Mateus - ES & 221 & 31.2 & $\mathrm{C}$ & Damázio et al. [67] \\
\hline 133 & Southeast & Sao Mateus - ES & 82 & 31.7 & $\mathrm{C}$ & Damázio et al. [66] \\
\hline 134 & Southeast & Sumidouro - RJ & 294 & 12.9 & $\mathrm{C}$ & Barbosa et al. [19] \\
\hline 135 & Southeast & Rio de Janeiro - RJ & 3245 & 6.8 & $\mathrm{C}$ & Faria et al. [81] \\
\hline 136 & Southeast & Rio de Janeiro - RJ & 595 & 12.2 & $\mathrm{C}$ & Ignácio et al. [109] \\
\hline 137 & Southeast & Rio de Janeiro - RJ & 180 & 10.5 & $\ldots$ & Valença-Barbosa et al. [214] \\
\hline 138 & Southeast & Niteroi - RJ & 68 & 17.6 & $\mathrm{C}$ & Leite et al. [120] \\
\hline 139 & Southeast & Niteroi - RJ & 1749 & 5.4 & $\mathrm{C}$ & Macedo et al. [126] \\
\hline 140 & Southeast & Niteroi - RJ & 429 & 11.6 & $\mathrm{C}$ & Uchôa et al. [213] \\
\hline 141 & Southeast & Rio de Janeiro - RJ & 218 & 1.4 & $\mathrm{C}$ & Carvalho-Costa et al. [51] \\
\hline 142 & Southeast & Niteroi - RJ & 140 & 15.7 & $\mathrm{C}$ & Port-Lourenço et al. [161] \\
\hline 143 & Southeast & Niteroi - RJ & 261 & 21.8 & $\mathrm{C}$ & Uchôa et al. [212] \\
\hline 144 & Southeast & $\mathrm{RJ}$ & 99 & 31.3 & $\mathrm{C}$ & Moura et al. [145] \\
\hline 145 & Southeast & Ribeirao Preto - SP & 233 & 13.3 & $\mathrm{C}$ & Fonseca et al. [91] \\
\hline 146 & Southeast & Sao Jose do Rio Preto - SP & 100 & 7.0 & $\mathrm{C}$ & Castro et al. [52] \\
\hline 147 & Southeast & Campos do Jordao - SP & 185 & 22.2 & $\mathrm{C}$ & Branco et al. [37] \\
\hline 148 & Southeast & Mirassol - SP & 310 & 15.1 & $\mathrm{C}$ & Belloto et al. [23] \\
\hline 149 & Southeast & Sao Jose do Rio Preto - SP & 500 & 0.8 & $\mathrm{C}$ & Cardoso et al. [48] \\
\hline 150 & Southeast & Sao Paulo - SP & 66 & 40.9 & $\mathrm{C}$ & Lopes et al. [123] \\
\hline 151 & Southeast & Catanduva - SP & 133 & 9.7 & $\mathrm{C}$ & Biscegli et al. [29] \\
\hline 152 & Southeast & Presidente Bernardes - SP & 101 & 8.9 & $\mathrm{C}$ & Tashima et al. [209] \\
\hline 153 & Southeast & Ribeirao Preto - SP & 429 & 9.3 & $\mathrm{C}$ & Capuano et al. [47] \\
\hline 154 & Southeast & Araraquara - SP & 503 & 14.5 & $\mathrm{C}$ & Miné and Rosa [139] \\
\hline 155 & Southeast & Sao Paulo - SP & 120 & 16.6 & $\mathrm{C}$ & Korkes et al. [115] \\
\hline 156 & Southeast & Catanduva - SP & 250 & 34.4 & $\mathrm{C}$ & Faleiros et al. [80] \\
\hline 157 & Southeast & Presidente Prudente - SP & 1000 & 7.1 & $\mathrm{C}$ & Tashima and Simões [208] \\
\hline 158 & Southeast & Sao Paulo - SP & 200 & 13.0 & $\mathrm{C}$ & Cimerman et al. [58] \\
\hline 159 & Southeast & Sao Jose da Bela Vista - SP & 1032 & 0.2 & $\mathrm{C}$ & Tavares-Dias and Grandini [210] \\
\hline 160 & Southeast & Botucatu - SP & 147 & 22.4 & $\mathrm{C}$ & Guimarães and Sogayar [102] \\
\hline 161 & Southeast & Holambra - SP & 222 & 15.7 & $\mathrm{C}$ & Kobayashi et al. [114] \\
\hline 162 & Southeast & Sao Paulo - SP & 407 & 1.5 & $\mathrm{C}$ & Ferreira et al. [88] \\
\hline 163 & Southeast & Osasco - SP & 155 & 21.3 & $\mathrm{Z}$ & Aca et al. [2] \\
\hline 164 & Southeast & Sao Paulo - SP & 395 & 25.8 & $\mathrm{C}$ & Guerra et al. [100] \\
\hline 165 & Southeast & Guarulhos - SP & 913 & 21.9 & $\mathrm{C}$ & Chieffi et al. [56] \\
\hline 166 & Southeast & Ribeirao Preto - SP & $\begin{array}{l}1351 \\
\text { Animal host }\end{array}$ & 23.1 & $\mathrm{C}$ & Ferriolli-Filho [90] \\
\hline 167 & Southeast & Rio de Janeiro - RJ & 13 (bird - emu) & 23.1 & $\mathrm{C}$ and $\mathrm{M}$ & Gallo et al. [93] \\
\hline 168 & Southeast & Rio de Janeiro - RJ & $\begin{array}{c}1190 \text { (non-human } \\
\text { primate) }\end{array}$ & 33.4 & $\mathrm{C}$ & Barbosa et al. [18] \\
\hline 169 & Southeast & Petropolis - RJ & 790 (pig) & 21.5 & $\mathrm{C}$ & Barbosa et al. [17] \\
\hline 170 & Southeast & Sao Paulo - SP & 21 (rodent - mouse) & 9.5 & $\mathrm{C}$ & Chagas et al. [55] \\
\hline 171 & Southeast & Bauru - SP & 47 (non-human primate) & 23.4 & $\mathrm{C}$ & David et al. [68] \\
\hline 172 & Southeast & Botucatu - SP & 207 (bird) & 1.9 & $\mathrm{C}$ & Marietto-Gonçalves et al. [132] \\
\hline 173 & Southeast & Sao Paulo - SP & 31 (canid - guara wolf) & 22.6 & $\mathrm{C}$ & Gilioli and Silva [95] \\
\hline 174 & Southeast & Sao Paulo - SP & 103 (edentate - anteater) & 4.8 & $\mathrm{C}$ & Diniz et al. [71] \\
\hline 175 & Northeast & $\mathrm{CE}-\mathrm{MA}-\mathrm{PI}-\mathrm{PE}-\mathrm{BA}$ & $340(\operatorname{dog})$ & 3.8 & $\mathrm{C}$ & Zanetti et al. [217] \\
\hline 176 & Northeast & Aracaju - SE & 44 (rodent - mouse) & 2.3 & $\mathrm{C}$ & Guimarães et al. [103] \\
\hline
\end{tabular}


Table 1. (Continued)

\begin{tabular}{|c|c|c|c|c|c|c|}
\hline No. & Region & City - State & Total $N$ & $\begin{array}{l}\text { Prevalence } \\
(\%)\end{array}$ & $\begin{array}{l}\text { Diagnostic } \\
\text { method }\end{array}$ & Author/year \\
\hline 177 & Northeast & Lajes - RN & $\begin{array}{c}64 \\
\text { (sheep) }\end{array}$ & 17.2 & $\mathrm{C}$ & Souza et al. [203] \\
\hline 178 & Northeast & Itabuna - BA & $119(\operatorname{dog})$ & 0.8 & $\mathrm{C}$ & Campos-Filho et al. [45] \\
\hline 179 & Northeast & Recife - PE & 685 (bird) & 5.7 & $\mathrm{C}$ & Freitas et al. [92] \\
\hline 180 & North & Sena Madureira - AC & 18 (bird) & 22.2 & $\mathrm{C}$ & Souza et al. [204] \\
\hline 181 & Midwest & Caceres - MT & $120(\operatorname{dog})$ & 15.8 & $\mathrm{C}$ & $\begin{array}{l}\text { Rosales and Malheiros } \\
\text { [173] }\end{array}$ \\
\hline 182 & South & $\mathrm{SC}$ & 217 (goat) & 1.8 & $\mathrm{C}$ & Radavelli et al. [164] \\
\hline
\end{tabular}

Abbreviations: MT - Mato Grosso; PR - Parana; PI - Piaui; RN - Rio Grande do Norte; PA - Para; MG - Minas Gerais; SE - Sergipe; BA Bahia; MS - Mato Grosso do Sul; ES - Espirito Santo; RJ - Rio de Janeiro; PB - Paraiba; RS - Rio Grande do Sul; SP - Sao Paulo; CE Ceara; AL - Alagoas; SC - Santa Catarina; DF - Federal District (capital of Brazil); MA - Maranhao; AP - Amapa; AM - Amazonas; RO Rondonia; GO - Goias; AC - Acre; PE - Pernambuco. C - conventional method, based on detection by optical microscopy; M - molecular method, based on DNA detection; E - Elisa method, serology-based; Z - zymodema method, based on isoenzyme analysis.

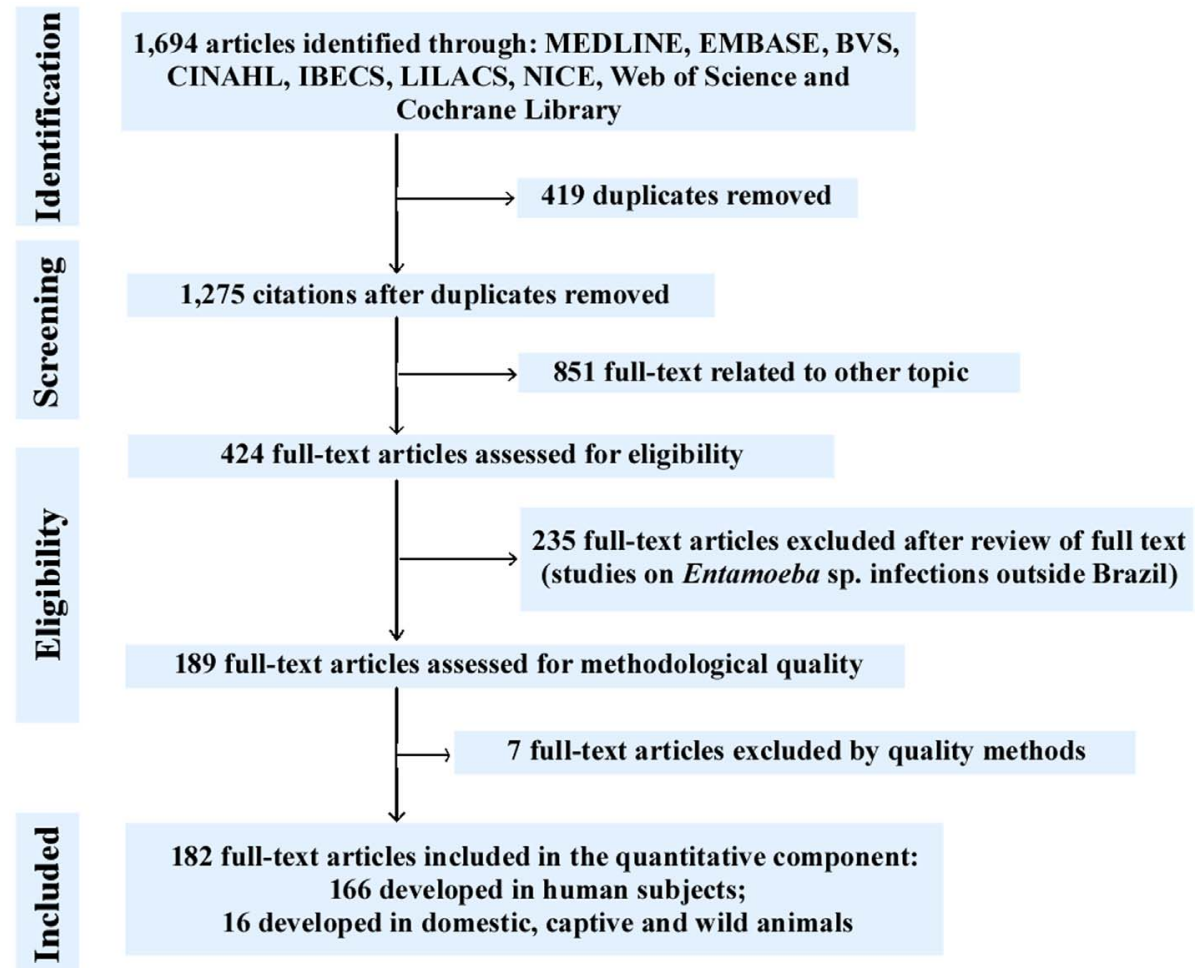

Figure 1. A flowchart of the steps performed in the systematic review.

reported compromized immune system, whereas $1785(0.7 \%)$ samples were from immunocompromized patients. Regarding the causes of immunosuppression, it was found that 1463 $(82 \%)$ samples were from human immunodeficiency virus (HIV) carriers, 249 (14\%) from patients undergoing hemodialysis, and $73(4 \%)$ from patients with cancer. Of the samples from immunosuppressed patients, 338 (19\%) were positive for Entamoeba spp.; 284 (84\%) of these patients had HIV, $28(8.3 \%)$ were undergoing hemodialysis, and $26(7.7 \%)$ had cancer.

\section{Pooled prevalence of Entamoeba spp.}

The prevalence of Entamoeba spp. reported in the analyzed studies was between $0.2 \%$ and $93.1 \%$. Random-effects meta-analysis showed a pooled prevalence of $22 \%$ (95\% CI: 21-24; weight $100 \%$ ) of Entamoeba spp. in the Brazilian population (Fig. 2).

The analysis of pooled prevalence by state showed that it was $72 \%$ in Paraiba, $53 \%$ in the Federal District, $50 \%$ in Rondonia, 35\% in Mato Grosso do Sul, 34\% in Mato Grosso 


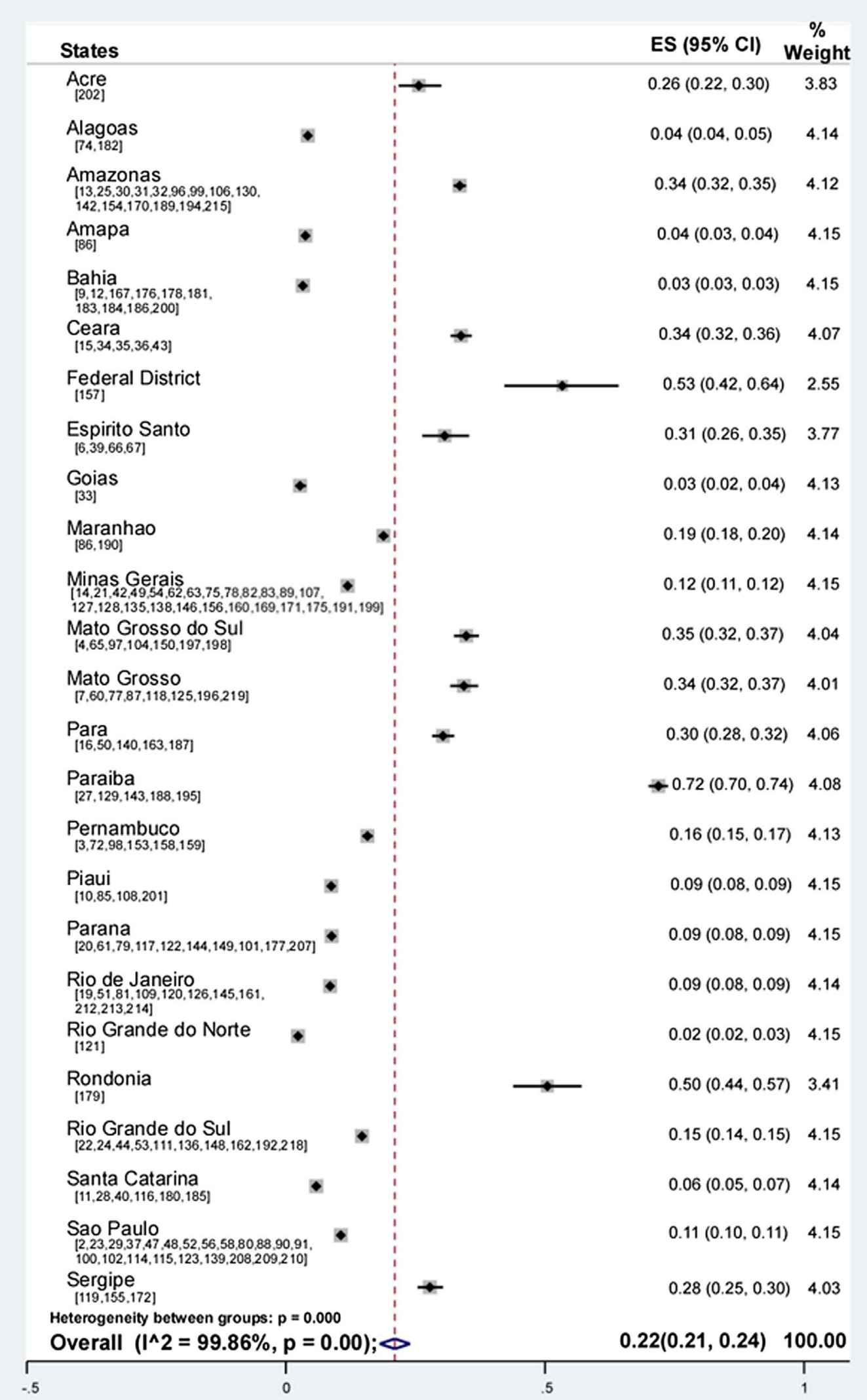

Figure 2. Forest plot for a random-effect meta-analysis of the pooled prevalence of Entamoeba spp. in the Brazilian population by state. In parentheses the studies used for each state. 
Table 2. Distribution of the pooled prevalence of Entamoeba spp. according to state and age.

\begin{tabular}{|c|c|c|c|c|c|c|c|c|c|c|c|c|}
\hline \multicolumn{4}{|c|}{ Overall } & \multicolumn{3}{|c|}{$\leq 9$} & \multicolumn{3}{|c|}{$10-19$} & \multicolumn{3}{|c|}{$>20$} \\
\hline State & $\begin{array}{c}\text { Overall } \\
\text { prevalence }\end{array}$ & $\begin{array}{c}95 \% \\
\text { CI }\end{array}$ & $\begin{array}{c}\text { Weight } \\
(\%)\end{array}$ & Prevalence & $\begin{array}{c}95 \% \\
\text { CI }\end{array}$ & $\begin{array}{c}\text { Weight } \\
(\%)\end{array}$ & Prevalence & $\begin{array}{c}95 \% \\
\text { CI }\end{array}$ & $\begin{array}{c}\text { Weight } \\
(\%)\end{array}$ & Prevalence & $\begin{array}{c}95 \% \\
\text { CI }\end{array}$ & $\begin{array}{c}\text { Weight } \\
(\%)\end{array}$ \\
\hline$\overline{\mathrm{PR}}$ & 13 & $1-25$ & 4.30 & 13 & $1-25$ & 7.16 & - & - & - & - & - & - \\
\hline SE & 31 & $27-36$ & 1.44 & 31 & $27-36$ & 2.39 & _- & - & _- & - & _- & - \\
\hline $\mathrm{RS}$ & 20 & $7-33$ & 5.63 & 15 & $2-29$ & 7.13 & - & - & - & 36 & $26-47$ & 5.19 \\
\hline PA & 34 & $30-39$ & 1.43 & 34 & $30-39$ & 2.38 & - & - & - & - & - & - \\
\hline MG & 33 & $22-45$ & 24.58 & 23 & $9-36$ & 22.36 & 45 & $24-67$ & 41.1 & 47 & $7-100$ & 21.17 \\
\hline $\mathrm{SP}$ & 19 & $13-26$ & 12.89 & 17 & $10-24$ & 14.31 & 34 & $28-41$ & 10.49 & 21 & $19-23$ & 10.72 \\
\hline MT & 28 & $6-50$ & 5.66 & 34 & $6-62$ & 7.10 & - & - & - & 9 & $4-20$ & 5.28 \\
\hline MA & 4 & $3-6$ & 1.45 & 4 & $3-6$ & 2.41 & - & - & - & - & - & - \\
\hline $\mathrm{AP}$ & 4 & $3-4$ & 1.45 & 4 & $3-4$ & 2.42 & - & - & - & - & - & - \\
\hline $\mathrm{SC}$ & 36 & $13-58$ & 4.06 & 36 & $13-58$ & 6.79 & - & - & - & - & - & - \\
\hline PB & 85 & $84-87$ & 2.9 & 85 & $84-87$ & 4.82 & - & - & - & - & - & - \\
\hline BA & 30 & $17-42$ & 6.3 & 13 & $9-16$ & 4.18 & 50 & $28-72$ & 6.99 & 20 & $16-25$ & 10.50 \\
\hline $\mathrm{AM}$ & 20 & $14-26$ & 9.88 & 16 & $8-24$ & 9.49 & 30 & $22-39$ & 10.18 & 26 & $21-32$ & 10.56 \\
\hline MS & 56 & $36-76$ & 5.50 & 55 & $45-64$ & 2.29 & 75 & $65-83$ & 10.11 & 51 & $44-57$ & 10.48 \\
\hline $\mathrm{RJ}$ & 22 & $17-27$ & 2.74 & 21 & $16-27$ & 2.38 & - & - & - & 26 & $15-40$ & 5.12 \\
\hline PE & 23 & $8-39$ & 5.7 & 25 & $20-30$ & 2.39 & 6 & $5-7$ & 21.13 & 35 & $28-41$ & 5.31 \\
\hline ES & 19 & $10-33$ & 1.33 & - & - & - & - & - & - & 19 & $10-33$ & 5.16 \\
\hline FD & 53 & $42-64$ & 1.34 & - & - & - & - & - & - & 53 & $42-64$ & 5.18 \\
\hline PI & 30 & $25-36$ & 1.42 & - & - & - & - & - & - & 30 & $25-36$ & 5.33 \\
\hline $\begin{array}{l}\text { Overall } \\
\quad \text { Prevalence }\end{array}$ & 29 & 24-34 & 100 & 25 & $18-31$ & 100 & 40 & $29-50$ & 100 & 34 & $20-47$ & 100 \\
\hline
\end{tabular}

Abbreviations: 95\% CI, 95\% confidence interval. PR - Parana, SE - Sergipe, RS - Rio Grande do Sul, PA - Para, MG - Minas Gerais, SP Sao Paulo, MT - Mato Grosso, MA - Maranhao, AP - Amapa, SC - Santa Catarina, PB - Paraiba, BA - Bahia, AM - Amazonas, MS, Mato Grosso do Sul, RJ - Rio de Janeiro, PE - Pernambuco, ES - Espirito Santo, DF - Federal District, PI - Piaui.

and Amazonas and Ceara, $31 \%$ in Espirito Santo, $30 \%$ in Para, $28 \%$ in Sergipe, $26 \%$ in Acre, $19 \%$ in Maranhao, $16 \%$ in Pernambuco, $15 \%$ in Rio Grande do Sul, $12 \%$ in Minas Gerais, $11 \%$ in Sao Paulo, 9\% in Parana, Piaui and Rio de Janeiro, 6\% in Santa Catarina, 4\% in Alagoas and Amapa, 3\% in Bahia and Goias, and $2 \%$ in Rio Grande do Norte (Fig. 2). The pooled prevalence with complete $95 \%$ CI values for each state is shown in Table 2.

Pooled prevalence by age group showed that the age group between 10 and 19 years had the highest prevalence $(40 \% ; 95 \%$ CI: 29-50; weight $100 \%$ ). The state with the highest prevalence in this age group was Mato Grosso do Sul (75\%), followed by Bahia (50\%), Minas Gerais (45\%), Sao Paulo (34\%), Amazonas (30\%), and Pernambuco (6\%). In the group over 19 years of age, the pooled prevalence was $34 \%(95 \% \mathrm{CI}$ : 20-47; weight $100 \%$ ). The state with the highest prevalence in this age group was the Federal District (53\%), followed by Mato Grosso do Sul (51\%), Minas Gerais (47\%), Rio Grande do Sul (36\%), Pernambuco (35\%), Piaui (30\%), Rio de Janeiro and Amazonas (26\%), Sao Paulo (21\%), Bahia (20\%), Espirito Santo (19\%), and Mato Grosso (9\%). Children below 9 years of age had a pooled prevalence of $25 \%$ (95\% CI: 18-31; weight $100 \%)$. The state with the highest prevalence for this age group was Paraiba (85\%), followed by Mato Grosso do Sul (55\%), Santa Catarina (36\%), Mato Grosso and Para (34\%), Sergipe (31\%), Pernambuco (25\%), Minas Gerais (23\%), Rio de Janeiro (21\%), Sao Paulo (17\%), Amazonas (16\%), Rio Grande do Sul (15\%), Parana and Bahia (13\%), and Maranhao and Amapa (4\%) (Table 2).
Table 3. Distribution of the pooled prevalence of Entamoeba spp. according to the type of immunosuppression.

\begin{tabular}{lccc}
\hline Immunosuppression & Overall subtotal & $95 \%$ CI & Weight (\%) \\
\hline Cancer & 36 & $26-47$ & 10.45 \\
HIV infection & 27 & $9-45$ & 55.96 \\
Hemodialysis & 10 & $2-18$ & 33.59 \\
Overall prevalence & 18 & $7-30$ & 100 \\
\hline
\end{tabular}

Abbreviations: 95\% CI, 95\% confidence interval.

The pooled prevalence in the 19,721 male samples was 26\% (95\% CI: 20-31; weight 100\%). The state with the highest prevalence was Para (57\%), followed by Pernambuco (33\%), Amazonas (28\%), Parana (20\%), Espirito Santo (19\%), Sao Paulo (18\%), Mato Grosso and Rio de Janeiro (15\%), Minas Gerais (8\%), Mato Grosso do Sul (7\%), and Bahia (1\%). In contrast, the pooled prevalence in the 36,721 female samples was $29 \%$ (95\% CI: 14-43; weight $100 \%$ ). The state with the highest prevalence of Entamoeba spp. in female samples was Mato Grosso do Sul (62\%), followed by Para (59\%), Amazonas (33\%), Espirito Santo (31\%), Pernambuco (25\%), Parana (21\%), Sao Paulo (19\%), Rio de Janeiro (11\%), Minas Gerais (7\%), and Mato Grosso (4\%).

The pooled prevalence in immunosuppressed patients was 18\% (95\% CI: 7-30; weight 100\%). The most prevalent cause of immunosuppression with Entamoeba spp. was cancer (36\%), followed by HIV infection (27\%), and hemodialysis (10\%) (Table 3). 


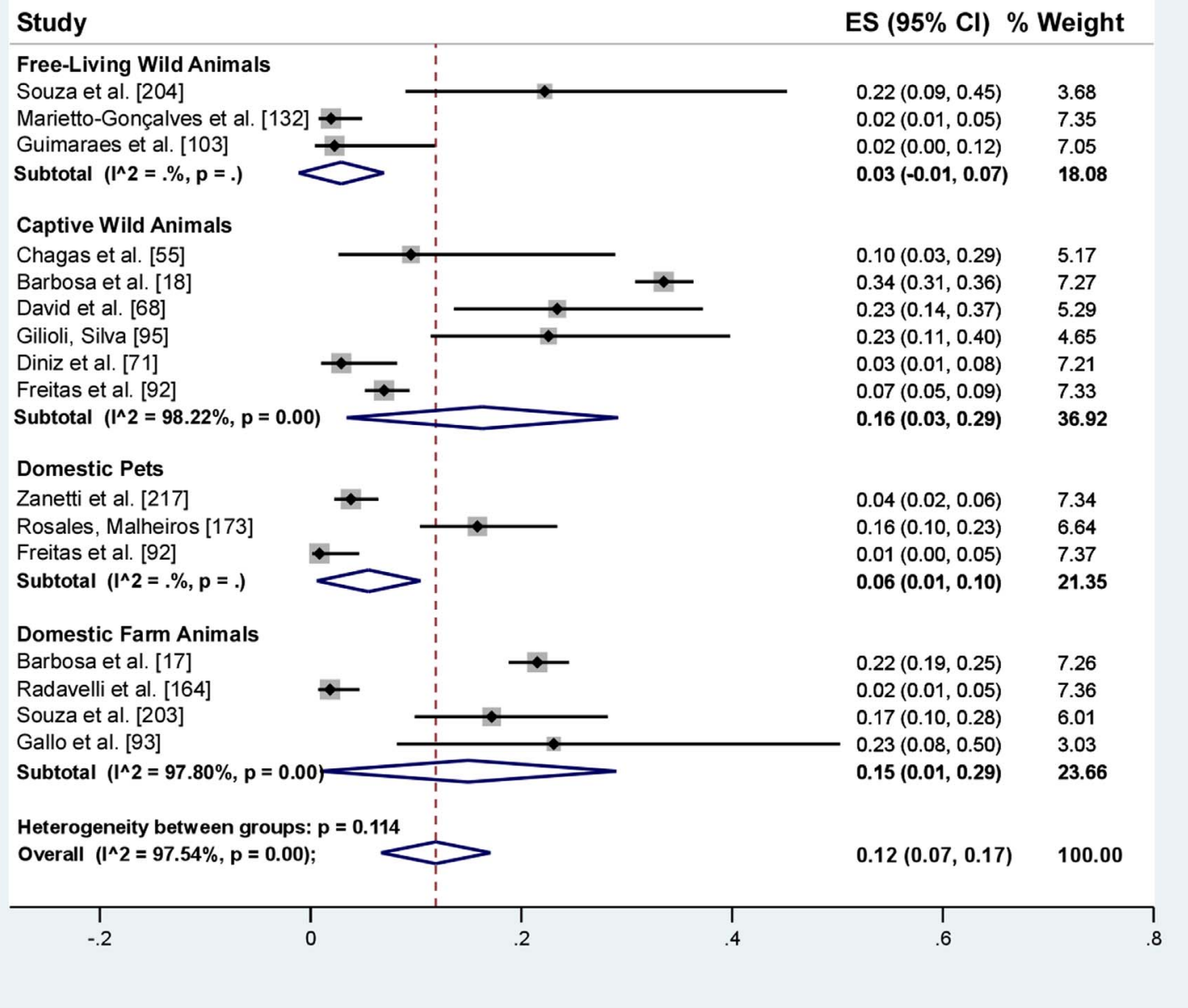

Figure 3. Forest plot for a random-effect meta-analysis of the pooled prevalence of Entamoeba spp. in different animals in Brazil, according to the type of interaction with humans.

\section{Entamoeba spp. in animals in Brazil}

The 16 studies that analyzed the prevalence of Entamoeba spp. in animals included 3805 coprological tests in different species $(79.1 \%$ mammals and $20.9 \%$ birds). The classification by direct interaction with humans showed that $54 \%$ were wild animals in captivity, $2.3 \%$ were free-living wild animals, $15.2 \%$ were pets, and $28.5 \%$ were farm animals.

The analysis of prevalence of Entamoeba spp. in Brazilian animals from different orders and with different types of human interaction showed a pooled prevalence of $12 \%(95 \% \mathrm{CI}$ : $7-17)$. Wild animals in captivity had a prevalence of $16 \%$ (95\% CI: 3-29), free-living wild animals 3\% (95\% CI: 1-7), farm animals $15 \%$ (CI95\%: 1-29.00), and pets 6\% (95\% CI: 1-10) (Fig. 3).

The prevalence of Entamoeba spp. by taxonomic class showed a prevalence of $12 \%$ (95\% CI: 6-19) in mammals and $6 \%$ (95\% CI: 1-12) in birds (Table 4).

Of the captive wild mammals, non-human primates were the most studied, with prevalence percentages of $34 \%$ and $23 \%$. In contrast, of the farm mammals, pigs had a prevalence of $22 \%$. Notably, the only animal considered a pet in the studies analyzed was the dog, representing $16 \%$ (Table 4). Of the domestic farm birds, emus had a prevalence of $23 \%$ and freeliving wild birds had a prevalence of $22 \%$ (Table 4).

\section{Entamoeba spp. diversity in different host species in Brazil}

Conventional microscopy analysis, molecular characterization, serology, and isoenzyme analysis were used to identify Entamoeba spp. in 150 studies, totaling 17,651 human samples. In contrast, only six studies on host animals characterized 51 positive samples at the species level.

To calculate the prevalence of the reported species, only the samples that performed this procedure were used. For this purpose, 17,651 samples (fecal and oral cavity) with identification of Entamoeba species, were used. In these samples, the most prevalent species identified in human hosts were $E$. coli (86.5\%), followed by E. dispar (7.9\%), E. histolytica (3.1\%), E. hartmanni (1.9\%), and E. gingivalis $0.6 \%$ (Fig. 4). The species identified as non-pathogenic E. histolytica, through zymodeme [2, 3], were considered as $E$. dispar. On the other 
Table 4. Distribution of the pooled prevalence of Entamoeba spp. according to taxonomic class and interaction with humans.

\begin{tabular}{|c|c|c|c|c|}
\hline Study & Taxonomic class & Overall prevalence $(\%)$ & $95 \% \mathrm{CI}$ & Weight $(\%)$ \\
\hline & Mammals & 12 & $6-19$ & 78.60 \\
\hline Guimarães et al. [103] & Rodents & 2 & $0-12$ & 7.05 \\
\hline Chagas et al. [55] & Rodents & 10 & $3-29$ & 5.17 \\
\hline Barbosa et al. [18] & Non-human primates & 34 & $31-36$ & 7.27 \\
\hline David et al. [68] & Non-human primates & 23 & $14-37$ & 5.29 \\
\hline Gilioli and Silva [95] & Guara wolf & 23 & $11-40$ & 4.65 \\
\hline Diniz et al. [71] & Anteaters & 3 & $1-8$ & 7.21 \\
\hline Zanetti et al. [217] & Dogs & 4 & $2-6$ & 7.34 \\
\hline Rosales and Malheiros [173] & Dogs & 16 & $10-23$ & 6.64 \\
\hline Campos-Filho et al. [45] & Dogs & 1 & $0-5$ & 7.37 \\
\hline Barbosa et al. [17] & Pigs & 22 & $19-25$ & 7.26 \\
\hline Radavelli et al. [164] & Goat & 2 & $1-5$ & 7.36 \\
\hline \multirow[t]{2}{*}{ Souza et al. [203] } & Sheep & 17 & $10-28$ & 6.01 \\
\hline & Birds & 6 & $1-12$ & 21.40 \\
\hline Souza et al. [204] & Birds & 22 & $9-45$ & 3.68 \\
\hline Marietto-Gonçalves et al. [132] & Birds & 2 & $1-5$ & 7.35 \\
\hline Freitas et al. [92] & Birds & 7 & $5-9$ & 7.33 \\
\hline \multirow{6}{*}{ Gallo et al. [93] } & Emus & 23 & $8-50$ & 3.03 \\
\hline & Interaction with humans & & & \\
\hline & Free-living wild animals & 3 & $1-7$ & 18.08 \\
\hline & Captive wild animals & 16 & $3-29$ & 36.92 \\
\hline & Domestic pets & 6 & $1-10$ & 21.35 \\
\hline & Domestic farm animals & 15 & $1-29$ & 23.66 \\
\hline
\end{tabular}

Abbreviations: 95\% CI, 95\% confidence interval

hand, E. coli was the only species with a taxonomic classification, identified in animal hosts. In addition, unidentified Entamoeba species were reported in animal hosts.

The prevalence of species by geographical regions showed that $E$. coli was the most prevalent species in the five regions, with high percentages. Entamoeba histolytica was identified in the north $(28.9 \%)$, northeast $(3.4 \%)$, south $(1.1 \%)$, and southeast $(0.3 \%)$ regions. The southeast region presented the greatest species diversity, with the identification of the five Entamoeba spp. registered in Brazil, followed by the northeast region with four species, north and south with three, and center-west with two different species (Fig. 4).

The detailed distribution of protozoan species by the Brazilian state is shown in Figure 4.

\section{Discussion}

Data on the prevalence of Entamoeba spp. were documented in 24 of 26 Brazilian states and in the Federal District. In this meta-analysis, a pooled prevalence of $22 \%$ of Entamoeba spp. was found in the Brazilian population. The pooled prevalence was calculated with samples of studies published between 1962 to 2020, so this percentage represents an overall prevalence of Entamoeba spp. in different hosts during this period of time, in Brazil. These results reflect a sampling of the five Brazilian regions, but the northeastern, southern, and southeastern regions are better characterized since these regions present higher scientific production. The northeastern region contributed 38 articles, representing $63.3 \%$ of the samples analyzed in this meta-analysis, the southern region 27 studies
(16.3\%), the southeastern region $62(12.3 \%)$, the northern region $23(6.7 \%)$, and the central-western region 17 studies $(1.4 \%)$.

The analysis of the prevalence of Entamoeba spp. by region showed contrasting realities within the states of each region. The northeastern region showed high pooled prevalence percentages in the states of Paraiba (72\%), Ceara (34\%), Sergipe (28\%), Pernambuco (16\%), Piaui $(9 \%)$ and Bahia (3\%). Alagoas and the Rio Grande do Norte showed another reality, with a prevalence of $4 \%$ and $2 \%$, respectively. The central-western region showed high pooled prevalence in the Federal District (53\%) and the states of Mato Grosso do Sul $(35 \%)$ and Mato Grosso (34\%), but the state of Goias presented a pooled prevalence of $3 \%$. In the northern region, the states of Rondonia (50\%), Para (30\%), Acre (26\%), Amazonas (30\%) and Maranhao (19\%) showed high percentages of prevalence, while and Amapa showed a prevalence of $4 \%$. In the southeastern region, the states of Espirito Santo, Minas Gerais and Sao Paulo showed a pooled prevalences of $31 \%, 12 \%$ and $11 \%$ respectively, while Rio Janeiro presented a moderate prevalence of $9 \%$. The same data were found for the southern region, where the state of Rio Grande do Sul had a high pooled prevalence of $15 \%$ and the states Parana and Santa Catarina had a moderate prevalence of $9 \%$ and $6 \%$, respectively.

The differences in the prevalence of intestinal parasites among the Brazilian regions were recently documented in a previous study [81]. However, in addition to the differences among the regions, this present study showed great prevalence differences within the same region. This epidemiological data can be used as a tool to identify areas of social vulnerability as intestinal parasitosis is strongly associated with the 


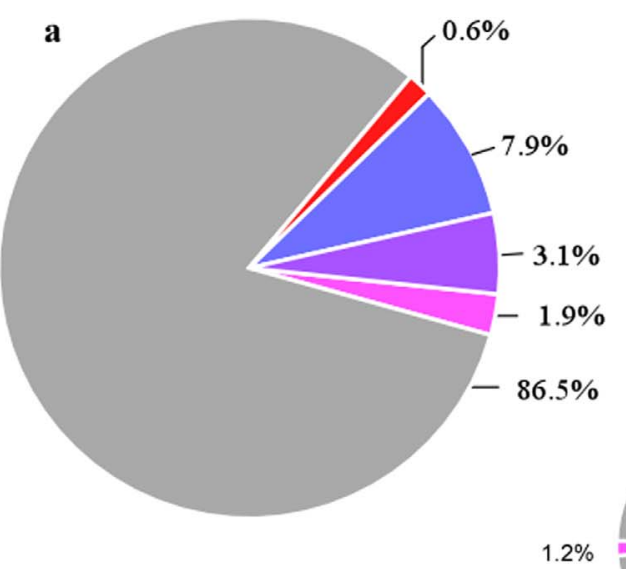

b

Entamoeba coli

Entamoeba dispar

Entamoeba histolytica

Entamoeba hartmanni

Entamoeba gingivalis

\section{Entamoeba gingivalis}

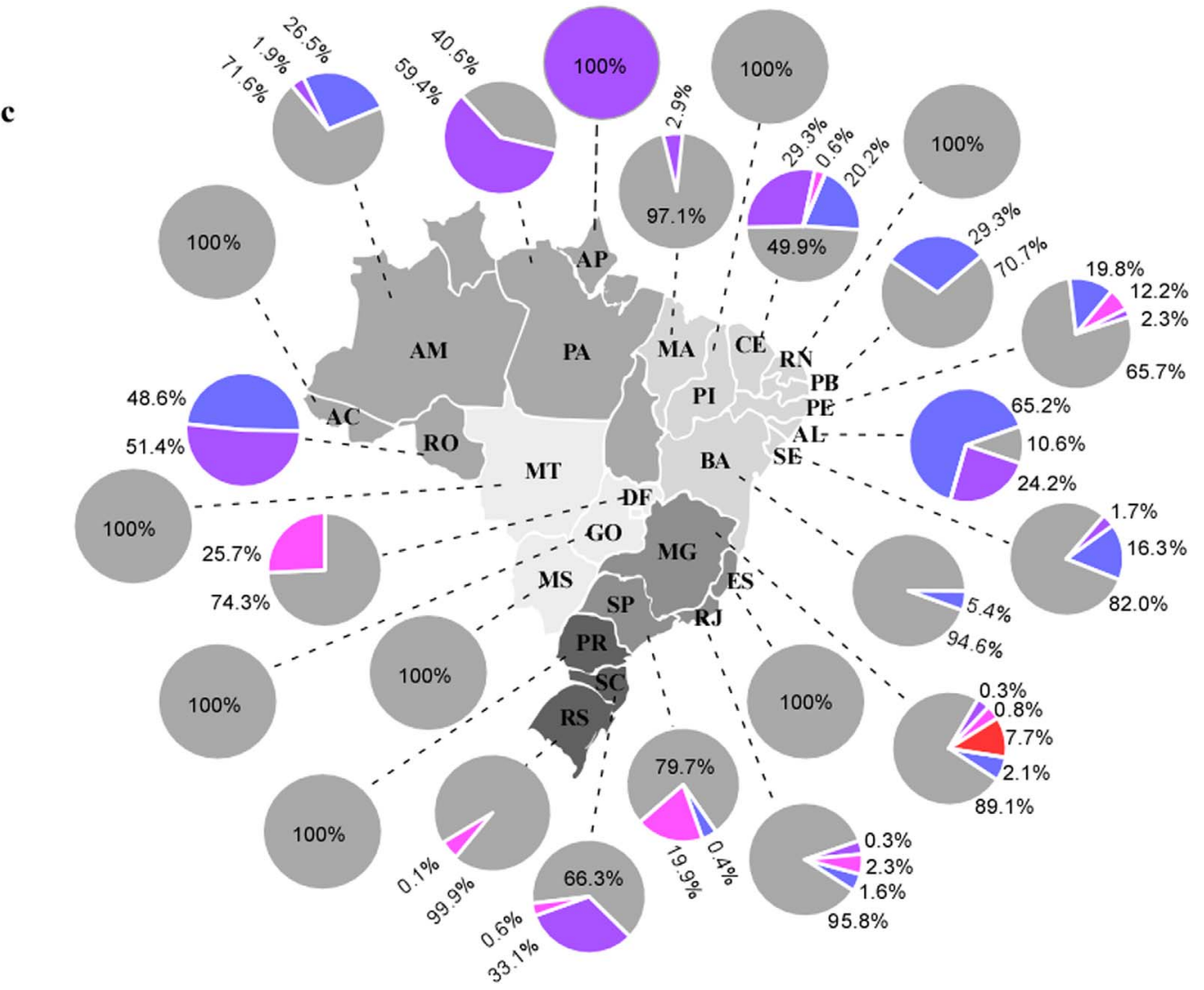

Figure 4. Geographical distribution of Entamoeba spp. detected in Brazil. (a) Species detected in 17,651 human samples. (b) Species distribution in human and animal hosts according to Brazilian regions. (c) Species distribution in human and animal hosts in Brazilian states. Abbreviations: AC - Acre; AM - Amazonas; RO - Rondonia; PA - Para; MA - Maranhao; PI - Piaui; CE - Ceara; RN - Rio Grande do Norte; PB - Paraiba; PE - Pernambuco; AL - Alagoas; SE - Sergipe; BA - Bahia; MG - Minas Gerais; ES - Espirito Santo; RJ - Rio de Janeiro; SP - Sao Paulo; PR - Parana; SC - Santa Catarina, RS - Rio Grande do Sul; MS - Mato Grosso do Sul; GO - Goias; MT - Mato Grosso; DF - Federal District (Capital of Brazil). 
socioeconomic level of the population. In contrast, Brazil is an extensive country and presents many regional and intraregional socioeconomic and health development differences. Only 39\% of the cities collect and treat $100 \%$ of the sewage [38], with the lack of adequate basic sanitation system increasing the continuous dissemination of neglected diseases linked to sanitary problems, such as intestinal parasitosis, including those caused by Entamoeba spp.

Regarding sex, both showed a similar pooled prevalence of Entamoeba spp., with $29 \%$ for women and $26 \%$ for men, suggesting that sex may not be a determinant for protozoan contamination. Regarding age, there was a high prevalence in the three groups, $40 \%$ in the $10-19$ years group, $34 \%$ in adults aged over 19 years, and $25 \%$ in children aged below 9 years.

Age is an important risk factor for intestinal parasitic infections. Children are often more susceptible to intestinal infectious diseases than adults owing to inadequate hygiene habits. Children aged below 9 years were the group that presented the highest number of samples analyzed in this meta-analysis, and even though it is the least prevalent for Entamoeba spp., $25 \%$ is a percentage of great importance within this population. In contrast, this study showed that the most prevalent group for Entamoeba spp. were the people aged 10-19 years. Therefore, school age represents a higher risk for amebiasis than the age of the general population. A previous study in Indonesia showed a high rate of Entamoeba spp. $(52.8 \%)$ in the school-age (7-15 years) group [137]. The age group between 10 and 19 years was the most heterogeneous, including pre-adolescents, adolescents, and young adults. However, this group provides a possible panorama for the prevalence of intestinal parasitosis in high school students in Brazil.

The pooled prevalence of Entamoeba spp. infection in immunocompromized patients was $18 \%$. This parasitic infection was most prevalent in cancer patients, with $36 \%$, although they presented fewer samples for analysis, followed by HIV and hemodialysis patients, with a prevalence of $27 \%$ and $10 \%$, respectively. Some studies indicate that this parasite frequently causes opportunistic infections in immunosuppressed patients [46, 111]; it was one of the most common causes of morbidity in this group. This study recorded high prevalence percentages in immunosuppressed patients, especially with cancer. Cancer, HIV, and hemodialysis patients become immunocompromized as a result of the disease itself or due to therapeutic procedures that cause immunosuppression $[134,193]$. Although intestinal parasitic infections are a great risk with persistent diarrhea and severe clinical symptoms in immunocompromized patients, the routine diagnosis of these infections is often ignored during chemotherapy or disease $[1,131]$. For this reason, it is extremely important to diagnose and treat parasitic infections to decrease morbidity in this group.

The overall pooled prevalence of Entamoeba spp. in animal hosts was $12 \%$. Of these animals, Entamoeba spp. was most prevalent in mammals $(12 \%)$, followed by birds (6\%). Regarding human interaction, Entamoeba spp. was most prevalent in captive wild animals, which are not easily accessible to the general population, followed by domestic farm animals. Farm animal breeding is a possible risk factor for Entamoeba spp. transmission. Therefore, it is necessary to establish control measures to minimize the transmission of these parasites among different animal hosts and humans.

For Entamoeba spp. diversity, this study showed little variability in human hosts, with differentiation into five different species. Studies on animal hosts characterized only E. coli. Of the species identified in humans, E. coli was the most prevalent $(86.5 \%)$, followed by E. dispar (7.9\%), E. histolytica (3.1\%), E. hartmanni $(1.9 \%)$, and E. gingivalis $(0.6 \%)$. The prevalence of these species in Brazil determined in this metaanalysis differed from the world scenario, which presented E. dispar with the highest prevalence $(49.4 \%)$, followed by E. histolytica $(32.3 \%)$, E. coli $(1.9 \%)$, and E. hartmanni $(0.9 \%)$ [64]. The Brazilian situation could be different if the 89 studies that used conventional identification methods also used molecular analysis in the 5234 samples to separate the species $E$. dispar from E. histolytica, which are morphologically indistinguishable and were not included in the general percentage.

Although this study presents the commensal parasite $E$. coli as the most prevalent in Brazil, it is important to highlight that this species has the same transmission route as that of other pathogenic species, such as E. histolytica, E. dispar, and even Giardia lamblia as well as helminths. The prevalence of this parasite can be used as an indicator of fecal/oral transmission, suggesting intestinal parasite transmission through water supply for human consumption or through contaminated food.

Entamoeba histolytica causes severe intestinal and extraintestinal amebiasis, representing a health risk in countries with inadequate sanitary barriers. This study identified significant prevalence and distribution percentages of E. histolytica in Brazil, with $28.9 \%$ prevalence in the north, $3.4 \%$ in the northeast, $1.1 \%$ in the south, and $0.3 \%$ in the southeast. In the central-western region, no study distinguished E. histolytica from E. dispar. It is important to note that more studies need to be developed in this region to resolve this sampling bias.

This study has some limitations. First, in human studies, some authors did not distribute the positive sample results by sex and/or age, decreasing the number of classified samples to better evaluate the prevalence by these variables. Second, many samples were not identified at the protozoan species level, which could improve data on the species distribution and prevalence in Brazil, especially those of the pathogenic E. histolytica. Finally, it is recommended that publication biases be evaluated using statistical methods in meta-analyses. However, the currently available methods, such as funnel graphs and the Egger regression test, are not considered useful in proportion studies [147].

In conclusion, this study showed a high prevalence of Entamoeba spp. in the Brazilian population (22\%), with a prevalence of up to $50 \%$ in the northern, northeastern, and central-western regions. Although there were contrasting prevalence percentages among the regions, there is a wide distribution of Entamoeba spp. in Brazil. There was no difference between males and females, and the age group of 10-19 years had the highest prevalence, broadly indicating the prevalence of intestinal parasitosis in high-school students in Brazil. The most diagnosed species was $E$. coli, which may suggest the transmission of intestinal parasites through water supply for human consumption or through contaminated food. This may lead to 
the possibility of infection due to other protozoan pathogenic species. The pathogenic species E. histolytica is distributed in most Brazilian regions, with significant prevalence percentages. The prevalence in mammals was the highest among animals, with interactions among humans and captive, wild, or domestic farm animals presenting the higher protozoan prevalence.

The implementation of molecular methods to detect Entamoeba spp. in scientific productions is extremely important to reduce possible false-negatives using coprological methods and to differentiate protozoan species. Patients with any type of immunosuppression should undergo routine intestinal protozoa screening and early treatment to avoid future complications because a significant prevalence was identified in this population.

Acknowledgements. The authors thank the National Council for Scientific and Technological Development (CNPq - Brazil), Universal Project 423391/2018-6 for funding. A.S.Z. received a fellowship from Mato Grosso State University.

\section{Conflicts of interest}

The authors declare that they have no conflicts of interest.

\section{References}

1. Abdel-Hafeez EH, Ahmad AK, Ali BA, Moslam FA. 2012. Opportunistic parasites among immunosuppressed children in Minia District, Egypt. Korean Journal of Parasitology, 50, 57-62.

2. Aca IS, França E Jr, Nozaki T, Freitas GB, Tateno S. 1993. Entamoeba histolytica zymodemes in children of Osasco, São Paulo. Revista do Instituto de Medicina Tropical de São Paulo, $35,581-582$.

3. Aca IS, Kobayashi S, Carvalho LZ Jr, Tateno S, Takeuchi T. 1994. Prevalence and pathogenicity of Entamoeba histolytica in three different regions of Pernambuco, northeast Brazil. Revista do Instituto Medicina Tropical de São Paulo, 36, 519-524.

4. Aguiar J, Goncalves A, Sodre F, Pereira SR, Boia M, Lemos E, Daher R. 2007. Intestinal protozoa and helminths among Terena Indians in the State of Mato Grosso do Sul: high prevalence of Blastocystis hominis. Revista da Sociedade Brasileira de Medicina Tropical, 40, 631-634.

5. Al-Habsi K, Yang R, Ryan U, Jacobson C, Miller DW. 2017. Morphological and molecular characterization of an uninucleated cyst-producing Entamoeba spp. in captured Rangeland goats in Western Australia. Veterinary Parasitology, 235, 41-46.

6. Albuquerque NO, Souza MAA. 2018. Análise parasitológica em estudantes com deficiência intelectual e/ou múltipla (o múltiple). Sociedad Iberoamericana de Información Científica, 2018, 1-7.

7. Alencar BT, Zanetti AS, Vilella SH, Araújo MSM, Silva LNL, Alencar RT, Espinosa AO, Malheiros AF. 2020. Fatores socioambientais e prevalência de enteroparasitas em pacientes em hemodiálise no pantanal mato-grossense, Brasil. Research, Society and Development, 9, e5109108738.

8. Ali IKM. 2015. Intestinal Amebae. Clinics in Laboratory Medicine, 35, 393-422.

9. Almeida PHA, Santana PCS, Silva AV. 2012. Prevalência de protozoários e helmintos entéricos em residentes de São Cristóvão, Feira de Santana, Bahia, Brasil. Arquivos de Ciências da Saúde UNIPAR, 16, 61-66.
10. Alves JR, Macedo HW, Ramos AN Jr, Ferreira LF, Gonçalves MLC, Araújo A. 2003. Parasitoses intestinais em região semiárida do Nordeste do Brasil: resultados preliminares distintos das prevalências esperadas. Caderno de Saúde Pública, 19, 667-670.

11. Andrade F, Rode G, Silva Filho HH, Greinert-Goulart JA. 2008. Parasitoses intestinais em um centro de educação infantil público do municipio de Blumenau (SC), Brasil, com ênfase em Cryptosporidium spp. e outros protozoários. Revista de Patologia Tropical, 37, 332-340.

12. Andrade RS, Albuquerque WA, Miranda FS, Marques BC, Mota LHS, Santos RS, Silva IMM, Amor AM. 2018. Presence of enteroparasites in the environment and the resident population in a rural community in Santo Antonio de Jesus in the reconcavo da Bahia, Brazil. Revista de Patologia Tropical, 47, 31-45.

13. Araújo CF, Fernández CL. 2005. Prevalência de parasitoses intestinais na cidade de Eirunepé, Amazonas. Revista da Sociedade Brasileira de Medicina Tropical, 38, 69.

14. Assis EM, Oliveira RC, Moreira LE, Pena JL, Rodrigues LC, Machado-Coelho GLL. 2013. Prevalência de parasitos intestinais na comunidade indígena Maxakali, Minas Gerais, Brasil, 2009. Cadernos de Saúde Pública, 29, 681-690.

15. Bachur TPR, Vale JM, Coêlho ICB, Queiroz TRBS, Chaves CS. 2008. Enteric parasitic infections in HIV/AIDS patients before and after the highly active antiretroviral therapy. Brazilian Journal of Infectious Diseases, 12, 115-122.

16. Banhos EF, Rocha JAM, Pimentel ML, Batista ETM, Silva LM. 2017. Prevalence and risk factors for intestinal parasite infections in schoolchildren, in the city of Santarém, Pará state, Brazil. Arquivos Brasileiros de Ciências da Saúde, 42, 137-142.

17. Barbosa AS, Bastos OMP, Dib LV, Siqueira MP, Cardozo ML, Ferreira LC, Chaves WT, Fonseca ABM, Uchôa CMA, Amendoeira MRR. 1995. Gastrointestinal parasites of swine raised in diferente management systems in the state of Rio de Janeiro, Brazil. Prequisa Veterinária Brasileira, 35, 941-946.

18. Barbosa AS, Pissinatti A, Dib LV, Siqueira MP, Cardozo ML, Fonseca ABM, Oliveira AB, Silva FA, Uchôa CMA, Bastos OMP, Amendoeira MRR. 2015. Balantidium coli and other gastrointestinal parasites in captives non-human primates of the Rio de Janeiro, Brazil. Journal of Medical Primatology, 44, 18-26.

19. Barbosa CV, Barreto MM, Andrade RJ, Sodré F, d'Avila-Levy CM, Peralta JM, Igreja RP, Macedo HW, Santos HLC. 2018. Intestinal parasite infections in a rural community of Rio de Janeiro (Brazil): prevalence and genetic diversity of Blastocystis subtypes. PLoS One, 13, e0193860.

20. Barbosa IA, Pavanelli MF. 2019. Alta prevalencia de Balantidium coli em crianças de uma escola municipal de Moreira Salas - PR. Arquivos de Ciências da Saúde UNIPAR, 23, 41-45.

21. Barçante TA, Cavalcanti DV, Silva GAV, Lopoes PB, Barros RF, Ribeiro GP, Neubert LF, Barçante JMP. 2008. Enteroparasitos em crianças matriculadas em creches públicas do município de Vespasiano, Minas Gerais. Revista de Patologia Tropical, 37, 33-42.

22. Basso RMC, Silva-Ribeiro RT, Soligo DS, Ribacki SI, Callegari-Jacques SM, Zoppas BCA. 2008. Evolução da prevalência de parasitoses intestinais em escolares em Caxias do Sul, RS. Revista da Sociedade Brasileira de Medicina Tropical, 41, 263-268.

23. Belloto MVT, Junior JES, Macedo EA, Ponce A, Galisteu KJ, Castro E, Tauyr LV, Rossit ARB, Machado RLD. 2011. Enteroparasitoses numa população de escolares da rede pública de ensino do município de Mirassol, São Paulo, Brasil. Revista Pan-Amazonica de Saúde, 2, 37-44.

24. Bencke A, Artuso GL, Reis RS, Barbieri NL, Rott MB. 2006. Enteroparasitoses em escolares residentes na periferia de Porto Alegre, RS, Brasil. Revista de Patologia Tropical, 35, 31-36. 
25. Benetton MLFN, Gonçalves AV, Meneghini MEF, Silva EF, Carneiro M. 2005. Risk factors for infection by the Entamoeba histolytica/E. dispar complex: na epidemiological study conducted in outpatient clinics in the city of Manaus, Amazon Region, Brazil. Transactions of the Royal Society of Tropical Medicine and Hygiene, 99, 532-540.

26. Berrilli F, Prisco C, Friedrich KG, Cerbo PD, Cave DD, Liberato CD. 2011. Giardia duodenalis assemblages and Entamoeba species infecting non-human primates in an Italian zoological garden: zoonotic potential and management traits. Parasites \& Vectors, 4, 199-206.

27. Bezerra AS, Cardoso VVBP, Barbosa VSA. 2018. Estado nutricional, anemia e parasitoses intestinais em gestantes de um municipio do Curimataú Paraibano. Revista de Atenção Primária à Saúde, 21, 399-407.

28. Biolchi LC, Collet ML, Dallanora FJ, D'Agostini FM, Nardi GM, Muller GA, Wagner G. 2015. Enteroparaistes and commensals in students aged 7 to 14 years in rural and urban áreas of Campos Novos, west of Santa Catarina, Brazil. Revista de Patologia Tropical, 44, 337-342.

29. Biscegli TS, Romera J, Candido AB, Santos JM, Candido ECA, Binotto AL. 2009. Estado nutricional e prevalência de enteroparsitoses em crianças matriculadas em creche. Revista Paulista de Pediatria, 27, 289-295.

30. Boia MN, Motta LP, Salazar MSP, Mutis MPS, Coutinho RBA, Coura JR. 1999. Estudo das parasitoses intestinais e da infecção chagásica no município de Novo Airão, estado do Amazonas, Brasil. Caderno de Saúde Pública, 15, 497-504.

31. Boia MN, Carvalho-Costa FA, Sodré FC, Eyer-Silva WA, Lamas CC, Lyra MR, Pinto-Junior VL, Cantalice-Filho JP, Oliveira ALL, Carvalho LMA, Gross JB, Souza ALS, Moraes TI, Bermudez-Aza EH, Martins EB, Coura JR. 2006. Mass treatment for intestinal helminthiasis control in na amazonian endemic área in Brazil. Revista do Intituto de Medicina Tropical de São Paulo, 48, 189-195.

32. Boia MN, Carvalho-Costa FA, Sodré FC, Porras-Pedroza BE, Faria EC, Magalhães GAP, Silva IM. 2009. Tuberculose e parasitismo intestinal em população indígena na Amazônia brasileira. Revista de Saúde Pública, 43, 176-178.

33. Borges WF, Marciano FM, Oliveira HB. 2011. Parasitos intestinais: elevada prevalencia de Giardia lamblia em pacientes atendidos pelo serviço público de saúde da região sudeste de Goiás, Brasil. Revista de Patologia Tropical, 40, 149-157.

34. Braga LL, Mendonça Y, Paiva CA, Sales A, Cavalcante ALM, Mann BJ. 1998. Seropositivity for and Intestinal Colonization with Entamoeba histolytica and Entamoeba dispar in Individuals in Northeastern Brazil. Journal of Clinical Microbiology, 36, 3044-3045.

35. Braga LLBC, Gomes ML, Silva MW, Façanha FE Jr, Fiuza L, Mann BJ. 2001. Household epidemiology of Entamoeba histolytica infection in an urban community in northeastern Brazil. American Journal of Tropical Medicine and Hygiene, 65, 268-271.

36. Braga LLBC, Gomes ML, Silva MW, Paiva C, Sales A, Mann BJ. 2001. Entamoeba histolytica and Entamoeba dispar infections as detected by monoclonal antibody in an urban slum in Fortaleza, Northeastern Brazil. Revista da Sociedade Brasileira de Medicina Tropical, 34, 467-471.

37. Branco N, Leal DAG, Franco RMB. 2012. A parasitological survey of natural water springs and inhabitants of a tourist city in southeastern Brazil. Vector-borne and Zoonotic Diseases, 12, 410-417.

38. Brasil. 2016. Ministério das Cidades; Secretaria Nacional de Saneamento Ambiental - SNSA. Sistema Nacional de Informações sobre Saneamento: diagnóstico dos serviços de água e esgotos - 2014. Brasília : SNSA/MCIDADES.
39. Brauer AMNW, Silva JC, Souza AA, Souoza MAA. 2017. Intestinal parasites among employees of restaurants and cafeterias in a city of Brazil. Revista de Salud Publica, 19, 691-696.

40. Bueno GCL, Reis M, Dantas-Correa EB, Schiavon LL, NarcisoSchiavon J. 2015. The prevalence of intestinal parasitosis according to gender in a university hospital in southern Brazil. Revista de Patologia Tropical, 44, 441-452.

41. Burrows RB. 1959. Morphological differentiation of Entamoeba hartmanni and $E$. polecki from E. histolytica. American Journal of Tropical Medicine and Hygiene, 8, 583-589.

42. Cabrine-Santos M, Cintra EN, Carmo RA, Nascentes GAN, Pedrosa AL, Correia D, Oliveira-Silva MB. 2015. Occurrence of Blastocystis spp. in Uberaba, Minas Gerais, Brazil. Revista do Instituto de Medicina Tropical de São Paulo, 57, 211-215.

43. Calegar DA, Nunes BC, Monteiro KJL, Santos JP, Toma HK, Gomes TF, Lima MM, Boia MN, Carvalho-Costa FA. 2016. Frequency and molecuar characterization of Entamoeba histolytica, Entamoeba dispar, Entamoeba moshkovskii, and Entamoeba hartmanni in the context of wáter scarcity in northeastern Brazil. Memórias do Instituto Oswaldo Cruz, 111, 114-119.

44. Camello JT, Cavagnolli NI, Spada PKWDS, Poeta J, Rodrigues AD. 2016. Prevalência de parasitoses intestinais e condições de saneamento básico das moradias em escolares da zona urbana de Caxias do Sul, Rio Grande do Sul. Scientia Medica, 26, ID 21716.

45. Campos-Filho PC, Barros LM, Campos JO, Braga VB, Cazorla IM, Albuquerque GR, Carvalho SMS. 2008. Parasitas zoonóticos em fezes de cães em praças públicas do município de Itabuna, Bahia, Brasil. Revista Brasileira de Parasitologia Veterinária, 17, 206-209.

46. Caner A, Zorbozan O, Tunali V, Kantar M, Aydogdu S, Aksoylar S, Guruz Y, Turgay N. 2019. Intestinal protozoan parasitc infections in immunocompromised child patients with diarrhea. Japanese Journal of Infectious Diseases, 73, 187-192.

47. Capuano DM, Lazzrini MPT, Junior EG, Takayanagui OM. 2008. Enteroparasitoses em manipuladores de alimentos do município de Ribeirão Preto - SP, Brasil, 2000. Revista Brasileira de Epidemiologia, 11, 687-695.

48. Cardoso LV, Galisteu KJ, Junior AS, Chahla LAOA, Canille RMS, Belloto MVT, Franco C, Maia IL, Rossit ARB, Machado RLD. 2011. Enteric parasites in HIV-1/AIDS - infected patients from a northwestern São Paulo reference unit in the highly active antirretroviral therapy era. Revista da Sociedade Brasileira de Medicina Tropical, 44, 665-669.

49. Carvalho GLX, Moreira LE, Pena JL, Marinho CC, Bahia MT, Machado-Coelho GLL. 2012. A comoparative study of the TFtest, Kato-Katz, Hoffman-Pons-Janer, Willis and BaermannMoraes coprologic methods for the detection of human parasitosis. Memórias do Instituto Oswaldo Cruz, 107, 80-84.

50. Carvalho APGC, Santos MCNP, Morais ROA, Pinto LC. 2019. Detection of intestinal parasites in public transport buses in Belém, Pará state, Northern Brazil. Revista de Patologia Tropical, 48, 170-178.

51. Carvalho-Costa FA, Gonçalves AQ, Lassance SL, Albuquerque CP, Leite JPG, Boia MN. 2007. Detection of Cryptosporidium spp. and other intestinal parasites in children with acute diarrhea and severe dehydration in Rio de Janeiro. Revista da Sociedade Brasileira de Medicina Tropical, 40, 346-348.

52. Castro EDR, Germini MCBY, Mascarenhas JDP, Gabbay YB, Lima ICG, Lobo PS, Fraga VD, Conceição LM, Machado RLD, Rossit ARB. 2015. Enteropathogens detected in a daycare center, southeastern Brazil: bacteria, vírus, and parasite research. Revista do Instituto de Medicina Tropical de São Paulo, 57, 27-32. 
53. Cavagnolli NI, Camello JT, Tesser S, Poeta J, Rodrigues AD. 2015. Prevalência de enteroparasitoses e análise socioeconómica de escolares em Flores da Cunha - RS. Revista de Patologia Tropical, 44, 312-322.

54. Cembranelli SBS, Souto FO, Ferreira-Paim K, Richinho TT, Nunes PL, Nascentes GAN, Ferreira TB, Correia D, Lages-Silva E. 2013. First evidence of genetic intraspecific variability and occurrence of Entamoeba gingivalis in HIV +/ AIDS. PLoS One, 8, e82864.

55. Chagas CRF, Gonzalez IHL, Favoretto SM, Ramos PL. 2017. Parasitological surveillance in a rat (Rattus norvegicus) colony in São Paulo Zoo animal house. Annals of Parasitology, 63, 291-297.

56. Chieffi PP, Waldman EA, Dias RMDS, Torres DMAGV, Chimara R, Mizumoto LC, Silva AMA, Uehara M. 1988. Enteroparasitoses no município de Guarulhos, SP, Brasil: prevalencia de infecção entre escolares residentes no bairro de Taboão, em junho de 1984. Revista do Instituto Adolfo Lutz, 48, 75-80.

57. Chihi A, Stensvold CR, Ben-Abda I, Ben-Romdhane R, Aoun K, Siala E, Bouratbine A. 2019. Development and evaluation of molecular tools for detecting and differentiating intestinal amoebae in healthy individuals. Parasitology, 146, 821-827.

58. Cimerman S, Cimerman B, Lewi DS. 1999. Revalence of intestinal parasitic infections in patients with acquired immunodeficiency syndrome in Brazil. International Journal of Infectious Diseases, 3, 203-206.

59. Clark CG, Kaffashian F, Tawari B, Windsor JJ, Twigg-Flesner A, Davies-Morel MCG, Blessmann J, Ebert F, Peschel B, Van AL, Jackson CJ, Macfarlane L, Tannich E. 2006. New insights into the phylogeny of Entamoeba species provided by analysis of four new small-subunit rRNA genes. International Journal of Systematic and Evolutionary Microbiology, 56, 2235-2239.

60. Coimbra CEA Jr, Santos RV. 1991. Parasitismo intestinal entre o grupo indígena Zoró, Estado de Mato Grosso (Brasil). Cadernos de Saúde Pública, 7, 100-103.

61. Colli CM, Mizutani AS, Martins VA, Ferreira ÉC, Gomes ML. 2014. Prevalence and risk factors for intestinal parasites in food handlers, southern Brazil. International Journal of Environmental Health Research, 24, 450-458.

62. Costa JO, Resende JÁ, Gil FF, Santos JFG, Gomes MA. 2018. Prevalence of Entamoeba histolytica and other enteral parasitic disease in the metropolitan region of Belo Horizonte, Brazil. A cross-sectional study. São Paulo Medical Journal, 136, 319-323.

63. Costa-Cruz JM, Cardoso MLG, Marques DE. 1995. Intestinal parasites in school food handlers in the city of Uberlândia, Minas Gerais, Brazil. Revista do Instituto de Medicina Tropical de São Paulo, 37, 191-196.

64. Cui Z, Li J, Chen Y, Zhang L. 2019. Molecular epidemiology, evolution, and phylogeny of Entamoeba spp. Infection, Genetics and Evolution, 75, e104018.

65. Curval LG, França AdO, Fernandes HJ, Mendes RP, de Carvalho LR, Higa MG, Ferreira EC, Dorval MEC. 2017. Prevalence of intestinal parasites among inmates in Midwest Brazil. PLoS One, 12, e0182248.

66. Damázio SM, Lima MS, Soares AR, Souza MAA. 2013. Intestinal parasites in a quilombola community of the northern state of Espírito Santo, Brazil. Revista do Instituto de Medicina Tropical de São Paulo, 55, 179-183.

67. Damázio SM, Soares AR, Souza MAA. 2016. Perfil parasitológico de escolares da localidade de Santa Maria, zona rural do município de São Mateus/ES, Brasil. Revista de Atenção Primária a Saúde, 19, 261-267.

68. David EB, Patti M, Coradi ST, Oliveira-Sequeira TCG, Ribolla PEM, Guimarães S. 2014. Molecular typing of Giardia duodenalis isolates from nonhuman primates housed in a
Brazilian zoo. Revista do Instituto de Medicina Tropical de São Paulo, 56, 49-54.

69. De Carli GA, Mentz M, Rott MB, Silva ACA, Wendorff A Tasca T, Castilhos DS, Hypolito L, Mylius L, Montenegro R, De Carli G. 1997. Prevalência das enteroparasitoses nas vilas periféricas da grande Porto Alegre, nos assentamentos de trabalhadores rurais e na cidade de arroio dos ratos no estado do Rio Grande do Sul. Revista Brasileira de Análises Clínicas, 29, 185-189.

70. Diamond LS, Clark CG. 1993. A redescription of Entamoeba histolytica Schaudinn, 1903 (Emended Walker, 1911) separating it from Entamoeba dispar Brumpt, 1925. Journal of Eukaryotic Microbiology, 40, 340-344.

71. Diniz LSM, Costa EO, Oliveira PMA. 1995. Clinical disorders observed in anteaters (Myrmecophagidae, Edentata) in captivity. Veterinary Research Communications, 19, 409-415.

72. Dourado A, Maciel A, Aca IS. 2006. Ocorrência de Entamoeba histolytica/Entamoeba dispar em pacientes ambulatoriais de Recife, PE. Revista da Sociedade Brasileira de Medicina Tropical, 39, 388-389.

73. Dolabella SS, Serrano-Luna J, Navarro-García F, Cerritos R, Ximénez C, Glaván-Moroyoqui JM, Silva FF, Tsutsumi V, Shibayama M. 2012. Amoebic liver abscess production by Entamoeba dispar. Annals of Hepatology, 11, 107-117.

74. Duarte IAC, Santos RV, Fontes G, Galindo LF, Ximenes RAA, Maciel MAV, Aca IS, Rocha EMM. 2013. Revalencia e infección por Entamoeba histolytica en escuelas publicas de la ciudad de Maceió, Alagoas, Brasil. Revista Cubana de Medicina Tropical, 65, 4-12.

75. Einloft ABN, Vitor CFH, Sant'Ana LFR, Priore SE, Franceschini SCC. 2010. Efeito das infecções parasitárias e da anemia materna sobre o peso ao nascer de crianas no município de Viçosa, MG. Revista Médica de Minas Gerais, 20, 317-322.

76. Elsheikha HM, Regan CS, Clark CG. 2018. Novel Entamoeba findings in nonhuman primates. Trends in Parasitology, 1, $12-25$.

77. Escobar-Pardo ML, Godoy APO, Machado RS, Rodrigues D, Neto UF, Kawakami E. 2010. Prevalência de parasitoses intestinais em crianças do Parque Indígena do Xingu. Jornal de Pediatria, 86, 493-496.

78. Eustachio PFP, Avelar LA, Dias JVL, Queiroz DRM, Murta NMG, Oliveira GHB, Cambraia RP, Pires HHR, Martins HR. 2019. Parasitismo intestinal y contaminación ambiental con helmintos y protozoários en una comunidade quilombola del sudeste de Brasil. Revista Cubana de Medicina Tropical, 71, 1-13.

79. Falavigna DLM, Almeida AA, Iwazaki RS, Araújo SM. 2008. Intestinal parasites in ecotourism región of the state of Paraná, Brazil. Brazilian Archives of Biology and Technology, 51, 693-699.

80. Faleiros JMM, Gallo G, Silva MMK, Raful R, Nasorri AR, Pipino LFR, Junqueira RB, Pinto PLS. 2004. Ocorrência de enteroparsitoses em alunos da escola pública de ensino fundamental do município de Catanduva (São Paulo, Brasil). Revista do Instituto Adolfo Lutz, 63, 243-247.

81. Faria CP, Zanini GM, Dias GS, Silva S, Freitas MB, Almendra R, Santana P, Sousa MC. 2017. Geospatial distribution of intestinal parasitic infections in Rio de Janeiro (Brazil) and its association with social determinats. PLoS Neglected Tropical Diseases, 11, e0005445.

82. Favoreto-Junior S, Machado MI. 1995. Estudos de frequência, morfologia e diagnóstico de Entamoeba gingivalis, Gross, 1849. Revista da Sociedade Brasileira de Medicina Tropical, 28, 379-387.

83. Felizardo AA, Souza LM, Siqueira RV, Kanamura HY. 2017. Prevalence and risk factors for intestinal parasitic infections in children attending daycare centers in Alfenas, Southern Minas Gerais, Brazil. Revista de Patologia Tropical, 46, 263-275. 
84. Feng M, Pandey K, Yanagi T, Wang T, Putaporntip C, Jongwutiwes S, Cheng X, Sherchand JB, Pandey BD, Tachibana H. 2018. Prevalence and genotypic diversity of Entamoeba species in inhabitants in Kathmandu, Nepal. Parasitology Research, 117, 2467-2472.

85. Fernandes NS, Guimarães HR, Amorim ACS, Brito VM, Borges EP, Reis MB, Trindade RA, Melo ACFL. 2014. Ocorrência de enteroparasitoses em manipuladores de alimentos de restaurantes em Parnaíba, Piauí-Brasil. Revista de Patologia Tropical, 43, 459-469.

86. Ferraz RRN, Barnabé AS, Porcy C, D’Eça Junior A, Feitosa T, Figueiredo PM. 2014. Parasitoses intestinais e baixos índices de Gini em Macapá (AP) e Timon (MA), Brasil. Cadernos de Saúde Coletiva, 22, 173-176.

87. Ferreira CS, Camargo LMA, Moitinho MLR, Azevedo RA. 1991. Intestinal parasites in Iaualapiti Indians from Xingu Park, Mato Grosso, Brazil. Memórias do Instituto Oswaldo Cruz, 86, 441-442.

88. Ferreira CS, Ferreira MU, Nogueira MR. 1994. The prevalence of infection by intestinal parasites in an urban slum in São Paulo, Brazil. Journal of Tropical Medicine and Hygiene, 97, 121-127.

89. Ferreira-Filho SR, Braga FCC, Sa DM, Nunes EB, Soares JSP, Padovese SM, Oliveira AC, Oliveira GMF, Passos G, Lemes HP. 2011. Entamoeba histolytica/Entamoeba dispar infection in chronic hemodialysis patients. Saudi Journal of Kidney Diseases and Transplantation, 22, 237-244.

90. Ferriolli-Filho F. 1962. Prevalência da Entamoeba histolytica e da Entamoeba hartmanni no município de Ribeirão Preto, São Paulo (Brasil). Revista do Instituto de Medicina Tropical de São Paulo, 4, 305-310.

91. Fonseca REP, Barbosa MCR, Ferreira BR. 2017. High prevalence of enteroparasites in children from Ribeirão Preto, São Paulo, Brazil. Revista Brasileira de Enfermagem, 70, 566-571.

92. Freitas MFL, Oliveira JB, Cavalcanti MB, Leite AS, Magalhaes VS, Oliveira RA, Sobrino AE. 2002. Parásitos gastrointetinales de aves silvestres en cautiverio en el estado de Pernambuco, Brasil. Parasitologia Latinoamericana, 57, 50-54.

93. Gallo SSM, Teixeira CS, Ederli NB, Oliveira FCR. 2019. Gastrointestinal parasites of a population of emus (Dromaius novaehollandiae) in Brazil. Brazilian Journal of Biology, 2019, $1-7$.

94. Garcia G, Ramos F, Pérez RG, Yañez J, Estrada MS, Mendoza LH, Martinez-Hernandez F, Gaytán P. 2014. Molecular epidemiology and genetic diversity of Entamoeba species in a chelonian collection. Journal of Medical Microbiology, 63, 271-283.

95. Gilioli R, Silva FA. 2000. Frequência de parasitas e infecção de Salmonella em lobo-guará, Chrysocyon brachyurus, mantido em zoológicos do estado de São Paulo, Brasil. Arquivos Brasileiros de Medicina Veterinária e Zootecnia, 52, 15-19.

96. Giugliano LG, Bernardi MGP, Vasconcelos JC, Costa CA, Giugliano R. 1986. Longitudinal study of diarrhoeal disease in a periurban community in Manaus, Amazon-Brazil. Annals of Tropical Medicine e Parasitology, 80, 443-450.

97. Gomes PDMF, Nunes VLB, Knechtel DS, Brilhante AF. 2010. Enteroparasitos em escolares do distrito Águas do Miranda, município de Bonito, Mato Grosso do Sul. Revista de Patologia Tropical, 39, 299-307.

98. Gonçalves JF, Tanabe M, Medeiros FPM, Gonçalves FJ, Aca IS, Motta SRN, Tateno S, Takeuchi T. 1990. Parasitological and serological studies on amoebiasis and other intestinal parasitic infections in the rural sector arond recife, northeast Brazil. Revista do Instituto de Medicina Tropical de São Paulo, 32, $428-435$
99. Gonçalves AQ, Abellana R, Pereira-da-Silva HD, Santos I, Serra PT, Julião GR, Orlandi PP, Ascaso C. 2014. Comparison of the performance of two spontaneous sedimentation techniques for the diagnosis of human intestinal parasites in the absence of a gold standard. Acta Tropica, 131, 63-70.

100. Guerra EM, Vaz AJ, Toledo LAS, Ianoni AS, Quadros CMS, Dias RMDS, Barretto OCO. 1991. Infecçoes por helmintos e protozoários intestinais em gestantes de primeira consulta antendidas em centros de saúde da rede estadual no subdistrito do Butantã, município de São Paulo. Revista do Instituto de Medicina Tropical de São Paulo, 33, 303-308.

101. Guilherme ALF, Araújo SM, Pupulim ART, Lima Júnior JE, Falavigna DLM. 2004. Parasitas intestinais e comensais em individuos de três vilas rurais do estado do Paraná, Brasil. Acta Scientiarum Health Sciences, 26, 331-336.

102. Guimarães S, Sogayar MIL. 1995. Occurrence of Giardia lamblia in children of municipal day-care centers from Botucatu, São Paulo state, Brazil. Revista do Instituto de Medicina Tropical de São Paulo, 37, 501-506.

103. Guimarães AO, Valença FM, Sousa JBS, Souza SA, Madi RR, Melo CM. 2014. Parasitic and fungal infections in synanthropic rodents in na área of urban expansion, Aracaju, Sergipe state, Brazil. Acta Scientiarum, 36, 113-120.

104. Higa-Júnior MG, Cardoso WM, Weis SMS, França AO, Pontes ERJC, Silva PV, Oliveira MP, Dorval MEMC. 2017. Intestinal parasitism among waste pickers in Mato Grosso do Sul, Midwest Brazil. Revista do Instituto de Medicina Tropical de São Paulo, 59, 1-6.

105. Higgins JPT, Green S. 2011. Cochrane handbook for systematic reviews of interventions [Internet]. London: The Cochrane Collaboration. Version 5.1.0. [cited 2020 Dez 20]. Available from: http://handbook-5-1.cochrane.org/.

106. Hurtado-Guerrero AF, Alencar FH, Hurtado-Guerrero JC. 2005. Ocorrência de enteroparasitas na população geronte de Nova Olinda do Norte - Amazonas, Brasil. Acta Amazonica, $35,487-490$.

107. Iasbik AF, Pinto PSA, Guimarães-Peixoto RPM, Santos TO, Fernandes FM, Silva LF, Silva AR, Vieira SE, Araújo JV. 2018. Prevalence and transmission of intestinal parasitosis in human beings from zona da mata, Minas Gerais, Brazil. Bioscience Journal, 34, 802-809.

108. Ibiapina AB, Leal JS, Santana PRA, Mesquita MR, Lopes TLC, Braz DC. 2020. Enteroparasitosis in patients attended by the health public service: epidemiology and spatial distribution. Scientia Medica, 30, 1-10.

109. Ignácio CF, Silva MECD, Handam NB, Alencar MFL, SoteroMartins A, Barata MML, Neto AHAM. 2017. Socioenvironmental conditions and intestinal parasitic infections in Brazilian urban slums: a cross-sectional study. Revista do Instituto de Medicina Tropical de São Paulo, 59, e56.

110. Jacob AS, Busby EJ, Levy AD, Komm N, Clark CG. 2016. Expanding the Entamoeba universe: new hosts yield novel ribosomal lineages. Journal of Eukaryotic Microbiology, 63, 69-78.

111. Jeske S, Bianchi TF, Moura MQ, Baccega B, Pinto NB, Berne MEA, Villela MM. 2018. Intestinal parasites in cancer patients in the South of Brazil. Brazilian Journal of Biology, 78, 574-578.

112. Ji T, Cao HX, Wu R, Cui LL, Su GM, Niu C, Zhang N, Wang SK, Zhou DH. 2019. Prevalence and genetic identification of three Entamoeba species in pigs in Southeastern China. Hindawi BioMed Research International, 2019, e2824017.

113. Jirků-Pomajbíková K, Čepička I, Kalousová B, Jirků M, Stewart F, Levecke B, Modrý D, Piel AK, Petrželková KJ. 2016. Molecular identification of Entamoeba species in savanna woodland chimpanzees (Pan troglodytes schweinfurthii). Parasitology, 143, 741-748. 
114. Kobayashi J, Hasegawa H, Forli AA, Nishimura NF, Yamanaka A, Shimabururo T, Sato Y. 1995. Prevalence of intestinal parasitic infection in five farms in Holambra São Paulo, Brazil. Revista do Instituto de Medicina Tropical de São Paulo, 37, 13-18.

115. Korkes F, Kumagai FU, Belfort RN, Szjnfeld D, Abud TG, Kleinman A, Florez GM, Szejnfeld T, Chieffi PP. 2007. Relationship between intestinal parasitic infection in children and soil contamination in na urban slum. Journal of Tropical Pediatrics, 55, 42-45.

116. Korzeniowski OM, Dantas W, Trabulsi LR, Guerrant RL. 1984. A controlled study of endemic sporadic diarrhoea among adult residents of southern Brazil. Transaction of the Royal Society of Tropical Medicine and Hygiene, 8, 363-373.

117. Kulik RA, Falavigna DL, Nishi L, Araujo SM. 2008. Blastocystis sp. and other intestinal parasites in hemodialysis patients. Brazilian Journal Infect Diseases, 12, 338-341.

118. Latorraca MQ, Meirelles SMP, Marchini JS. 1988. Indicadores das condições nutricionais na região polonoroeste versos desnutrição protéico-energética e parasitoses intestinais em um grupo de crianças de 3 a 72 meses de idade da cidade de Mirassol D’Oeste, Mato Grosso, Brasil. Revista do Instituto de Medicina Tropical de São Paulo, 30, 192-196.

119. Lawson LLO, Bailey JW, Beeching NJ, Gurgel RG, Cuevas LE. 2004. The stool examination reports amoeba cysts: should you treat in the face of over diagnosis and lack of specificity of light microscopy? Tropical Doctor, 34, 28-30.

120. Leite RO, Toma HK, Adani YL. 2014. Diagnóstico parasitológico e molecular de enteroparsitos entre crianças residentes e funcionários de uma instituição beneficente para menores no município de Niterói-RJ, Brasil. Revista de Patologia Tropical, 43, 446-458.

121. Lima ECS, Leon CMP, Oliveira HMBF, Barbosa VSA. 2020. Prevalência de parasitoses intestinais em usuários de um hospital universitário, Santa Cruz-RN, Brasil. Revista de Atenção a Saúde, 18, 21-30.

122. Lopes FMR, Gonçalves DD, Reis CR, Breganó RM, Anaruma Filho F, Murad VA, Menezes MCND, Freire RL, Freitas JC, Santana MAZ, Navarro IT. 2006. Occurrence of enteroparasitosis in schoolchildren of the municipal district of Jataizinho, State of Paraná Brazil. Acta Scientiarum Health Sciences, 28, 107-111.

123. Lopes LM, Santos ES, Savegnago TL, Salvador FA, RibeiroBarbosa ER. 2010. Ocorrência de parasitas e comensais intestinais em crianças da comunidade de Vila Inglesa em São Paulo, SP, Brasil. Revista do Instituto Adolfo Lutz, 69, 252-254.

124. López MC, León CM, Fonseca J, Reyes P, Moncada L, Olivera MJ, Ramírez JD. 2015. Molecular epidemiology of Entamoeba: first description of Entamoeba moshkovskii in a rural area from Central Colombia. PLoS One, 10, e0140302.

125. Luz JGG, Carvalho AG, Marques AP, Marcondes AA, Roma JHF, Castro LS, Castro LS, Dias JVL, Pavoni JHC. 2017. Intestinal parasitic infections and associated risk factors in preschoolers from different urban settings in Central-Western Brazil. Asian Pacific Journal of Tropical Disease, 7, 405-410.

126. Macedo HW, Gonçalves AMH, Almeida CB, Dias LVB, Muniz MF. 2010. Infecção por Blastocystis hominis e Entamoeba histolytical Entamoeba dispar em pacientes atendidos em um hospital localizado em Niterói, Rio de Janeiro. Revista de Patologia Tropical, 39, 56-62.

127. Machado ER, Santos DS, Costa-Cruz JM. 2008. Enteroparasites and commensals among children in four peripheral districts of Uberlândia, satate of Minas Gerais. Revista da Sociedade Brasileira de Medicina Tropical, 41, 581-585.

128. Machado ER, Souza TS, Costa JM, Costa-Cruz JM. 2008. Enteroparasites and commensals among individuals living in rural and urban áreas in Adadia dos Dourados, Minas Gerais state, Brazil. Parasitología Latinoamericana, 63, 34-39.

129. Magalhães VM, Carvalho AG, Freitas FIS. 2010. Inquérito parasitológico em manipuladores de alimentos em João Pessoa, PB, Brasil. Revista de Patologia Tropical, 39, 335-342.

130. Maia MMM, Fausto MA, Vieira ELM, Benetton MLFN, Carneiro M. 2009. Intestinal parasitic infection and associated risk factors, among children presenting at outpatient clinics in Manaus, Amazonas state, Brazil. Annals of Tropical Medicine \& Parasitology, 103, 583-591.

131. Marcos LA, Gotuzzo E. 2013. Intestinal protozoan infections in the immunocompromised host. Current Opinion in Infectious Diseases, 26, 295-301.

132. Marietto-Gonçalves GA, Fernandes TM, Silva RJ, Lopes RS, Andreatti Filho RL. 2008. Intestinal protozoan parasites with zoonotic potential in birds. Parasitology Research, 103, 12371240.

133. Markell EK, John DT, Krotoski WA. 2003. Protozoários que habitam a luz, in Parasitologia médica, Markell EK, Editor. Guanabara-Koogan: Rio de Janeiro. p. 265-283.

134. Marques AB, Pereira DC, Ribeiro RC. 2005. Motivos e frequência de internação dos pacientes com IRC em tratamento hemodialítico. Arquivos de Ciências da Saúde, 12, 67-72.

135. Martins LPA, Serapião AATB, Valenciano RF, Oliveira GT, Santos KJA, Castanho REP. 2009. Avaliação inicial da prevalência de algumas enteroparasitoses na comunidade de Palmital, município de Berilo-MG. Revista Médica de Minas Gerais, 19, 26-31.

136. Mata-Santos T, Gatti FA, Mascarenhas CS, Martins LH, MataSantos HA, Fenalti JM, Netto ICO, Mendoza-Sassi RA, Scaini CJ. 2013. Prevalence of enteroparasites in children atended at basic health unities in a Brazilian southern city. Revista do Instituto Adolfo Lutz, 72, 175-178.

137. Matsumura $T$, Hendarto $J$, Mizuno $T$, Syafruddin $D$, Yoshikawa H, Matsubayashi M, Nishimura T, Tokoro M. 2019. Possible Pathogenicity of commensal Entamoeba hartmanni revealed by molecular screening of healthy school children in Indonesia. Tropical Medicine and Health, 47, 7-15.

138. Menezes AL, Lima VMP, Freitas MTS, Rocha MO, Silva EF, Dolabella SS. 2008. Prevalence of intestinal parasites in children from public daycare center in the city of Belo Horizonte, Minas Gerais, Brazil. Revista do Instituto de Medicina Tropical de São Paulo, 50, 57-59.

139. Miné JC, Rosa JA. 2008. Frequency of Blastocystis hominis and other intestinal parasites in stool samples examined at the parasitology laboratory of the School of Pharmaceutical Sciences at the São Paulo State University, Araraquara. Revista da Sociedade Brasileira de Medicina Tropical, 41, 565-569.

140. Miranda RA, Xavier FB, Menezes RC. 1998. Parasitismo intestinal em uma aldeia indígena Parakanã, sudeste do estado do Pará, Brasil. Caderno de Saúde Pública, 14, 507-511.

141. Moher D, Liberati A, Tetzlaff J, Altman DG. 2009. Preferred reporting items for systematic reviews and meta-analyses: the PRISMA statement. PLoS Medicine, 6, e1000097.

142. Monteiro AMC, Silva EF, Almeida KS, Sousa JJN, Mathias LA, Baptista F, Freitas FLC. 2009. Parasitoses intestinais em crianças de creches públicas localizadas em bairros periféricos do município de Coari, Amazonas, Brasil. Revista de Patologia Tropical, 38, 284-290.

143. Monteiro ACS, Soares DA, Diniz SCPOR, Cavalcante UMB, Silva AB, Vianna RPT, Freitas FIS, Souza TC, Lima CMBL. 2018. Intestinal parasitismo and related risk factors for primary school students in the municipality of João Pessoa, Northeast Brazil. Bioscientia Journal, 34, 1062-1072. 
144. Mortean ECM, Falavigna DLM, Janeiro V, FalavignaGuilherme AL, Gomes ML. 2012. Low intestinal parasites as an health indicator in a municipality of southern Brazil with intesnive agricultural mechanization. Revista de Saúde e Biologia, 7, 23-29.

145. Moura H, Fernandes O, Viola JPB, Silva SP, Passos RH, Lima DB. 1989. Enteric parasites and HIV infection: occurrence in AIDS patients in Rio de Janeiro, Brazil. Memórias do Instituto Oswaldo Cruz, 84, 527-533.

146. Moura RGF, Ramos ELP, Colombo MS, Aidar FLM, Hernández CG, Silva MBO, Oliveira KR. 2017. Prevalence of intestinal parasites in child daycare centers: epidemiological significance. Revista de Patologia Tropical, 46, 75-84.

147. Murad MH, Chu H, Lin L, Wang Z. 2018. The effect of publication bias magnitude and direction on the certainty in evidence. BMJ Evidence Based Medicine, 23, 84-86.

148. Nagel AS, Baccega B, Hernandes JC, Santos CV, Gallo MC, Quevedo PS, Villela MM. 2017. Intestinal parasite prevalence in shoolchildren from northwestern Rio Grande do Sul state, Brazil. Revista de Patologia Tropical, 46, 277-286.

149. Nascimento SA, Moitinho MLR. 2005. Blastocystis hominis and other intestinal parasites in a community of Pitanga city, Paraná state, Brazil. Revista do Instituto de Medicina Tropical de São Paulo, 47, 213-217.

150. Neres-Norberg A, Guerra-Sanches F, Moreira-Norberg PRB, Madeira-Oliveira JT, Santa-Helena AA, Serra-Freire NM. 2014. Enteroparasitismo en indígenas Terena em el Estado de Mato Grosso do Sul, Brasil. Revista de Salud Publica, 16, 859-870.

151. Ngobeni R, Samie A, Moonah S, Watanabe K, Petri WA, Gilchrist C. 2017. Entamoeba species in South Africa: correlations with the host microbiome, parasite burdens, and first description of Entamoeba bangladeshi outside of Asia. Journal of Infectious Diseases, 216, 1592-1600.

152. Nolan MJ, Unger YYT, Rogers E, Millet I, Harman K, Fox M, Kalema-Zikusoka G, Blake DP. 2017. Molecular characterisation of protest parasites in human-habituated mountain gorillas (Gorilla beringei beringei), humans and livestock, from Bwindi impenetrable National Park, Uganda. Parasites \& Vectors, 10, 340-355.

153. Okazaki M, Okazaki M, Miranda P, Neto J, Diegues V, Alves J, Cauas M, Tanabe M, Kobayashi S, Kaneko N, Nagakura K, Kobayashi M, Motta S, Tateno S, Takeuchi T. 1988. Parasitological and serological studies on amoebiasis and other intestinal parasitic infections in recife and its suburban area, northeast Brazil. Revista do Instituto de Medicina Tropical de São Paulo, 30, 313-321.

154. Oliveira CLM, Ferreira WA, Vasquez FG, Barbosa MGV. 2010. Parasitoses intestinais e fatores socioambientais de uma população da área periurbana de Manaus - AM. Revista Brasileira em Promoção da Saúde, 23, 307-315.

155. Oliveira YLDC, Oliveira LM, Oliveira YLM, Nascimento AMD, Corte RL, Geraldini RM, Barbosa L, Gazzinelli-Guimarães PH, Fujiwara RT, Bueno LL, Dolabella SS. 2020. Changes in the epidemiological profile of intestinal parasites after a school-based large-scale treatment for soil-transmitted helminths in a community in northeastern Brazil. Acta Tropica, 202, ID 105279.

156. Pereira VV, Conceição AS, Maximiano LHS, Belligoli LQG, Silva ES. 2014. Laboratory diagnosis of amebiasis in a sample of students from southeastern Brazil and a comparison of microscopy with enzyme-linked immunosorbent assay for screening of infections with Entamoeba sp. Revista da Sociedade Brasileira de Medicina Tropical, 47, 52-56.

157. Pereira IGS, Rodrigues CS, Gurgel-Gonçalves R, Machado ER. 2015. Frequency of intestinal parsites and commensals in street waste pickers from two cooperatives in the Brazilian Federal district. Revista de Patologia Tropical, 44, 432-440.
158. Pinheiro SMB, Carneiro RM, Aca IS, Irmão JI, Morais JRMA, Coimbra MRM, Carvalho JRLB. 2004. Determination of the prevalence of Entamoeba histolytica and E. dispar in the Pernambuco state of northeastern Brazil by a polymerase chain reaction. American Journal of Tropical Medicine and Hygiene, 70, 221-224.

159. Pinheiro SMB, Maciel RF, Morais JRMA, Aca IS, Carvalho JRLB, Coimbra MRM. 2005. Genetic characterization of Entamoeba dispar isolates in Northeast Brazil. Acta Tropica, 94, 35-40.

160. Pires ECR, Guimarães FP, Diniz JC, Froeseler MVG, Mata LCC. 2016. Abordagem interdisciplinar das parasitoses intestinais em escolares da microrregião de Sete Lagoas-MG. Arquivos de Ciências da Saúde UNIPAR, 20, 111-116.

161. Port-Lourenço AE, Uchoa ACM, Bastos MPO. 2004. Hospital food handlers in Niterói, RJ, Brazil: intestinal parasitism. Archivos Latinoamericanos de Nutrición, 54, 395-401.

162. Porto LP, Cavagnolli NI, Reis DS, Spada PKWDS, Rodrigues AD. 2016. Prevalência de parasitoses em trabalhadores de restaurantes de Caxias do Sul - RS. Revista de Patologia Tropical, 45, 115-120.

163. Póvoa MM, Arruda JEG, Silva MCM, Bichara CNC, Esteves P, Gabbay YB, Machado RLD. 2000. Diagnóstico de amebíase intestinal utilizando métodos coproscópicos e imunológicos em amostras da população da área metropolitana de Belém, Pará, Brasil. Cadernos de Saúde Pública, 16, 843-846.

164. Radavelli WM, Pazinato R, Klauck V, Volpato A, Balzan A, Rossett J, Cazorotto CJ, Lopes LS, Kessler JD, Cucco DC, Tonin AA, Da Silva AS. 2014. Occurrence of gastrointestinal parasites in goats from the western Santa Catarina, Brazil. Brazilian Journal of Veterinary Parasitology, 23, 101-104.

165. Ragazzo LJ, Zohdy S, Velonabison M, Herrera J, Wright PC, Gillespie TR. 2018. Entamoeba histolytica infection in wild lemurs associated with proximity to humans. Parasitology Research, 249, 98-101.

166. Raza A, Iqbal Z, Muhammad G, Ahmad M, Hanif K. 2013. Amebiasis as a major risk to human health: a review. International Journal of Molecular Medical Science, 3, 13-24.

167. Reis LB, Santos RS, Mota LHS, Jesus JSA, Oliveira JMO, Andrade RS, Santos GA, Amor ALM. 2019. Enteroparasites, demographic profile socioeconomic status and education level in the rural popuolation of the recôncavo of Bahia, Brazil. Revista de Patologia Tropical, 48, 197-210.

168. Review Manager (Computer program). 2020. Version 5 The Cochrane Collaboration. Available at: https://training. cochrane.org/online-learning/core-software-cochrane-reviews/ revman/revman-5-download.

169. Rezende CHA, Costa-Cruz JM, Gennari-Cardoso ML. 1997. Enteroparasitoses em manipuladores de alimentos de escolas públicas em Uberlândia, Minas Gerais, Brasil. Revista Panamericana de Salud Publica, 2, 392-397.

170. Rios L, Cutolo AS, Giatti LL, Castro M, Rocha AA, Toledo RF, Pelicioni MCF, Barreira LP, Santos JG. 2007. Prevalência de parasitos intestinais e aspectos socioambientais em comunidade indígena no distrito de Iauaretê, município de São Gabriel da Cachoeira-AM, Brasil. Revista Saúde e Sociedade, 16, 76-86.

171. Rocha RS, Silva JG, Peixoto SV, Caldeira RL, Firmo JOA, Carvalho OS, Katz N. 2000. Avaliação da esquistossomose e de outras parasitoses intestinais, em escolares do município de Bambuí, Minas Gerais, Brasil. Revista da Sociedade Brasileira de Medicina Tropical, 33, 431-436.

172. Rollemberg CVV, Silva MMBL, Rollemberg KC, Amorim FR, Lessa NMN, Santos MDS, Souza AMB, Melo EV, Almeida RP, Silva AM, Werneck GL, Santos MA, Almeida JAP, Jesus AR. 2015. Predicting frequency distribution and influence of sociodemographic and behavioral risk factors of 
Schistosoma mansoni infection and analysis of co-infection with intestinal parasites. Geospatial Health, 10, 13-19.

173. Rosales TFL, Malheiros AF. 2017. Contaminação ambiental por enteroparasitas presentes em fezes de cães em uma região do Pantanal. O Mundo da Saúde, 41, 368-377.

174. Royer TL, Gilchrist C, Kabir M, Arju T, Ralston KS, Haque R, Clark CG, Petri-Junior WA. 2012. Entamoeba bangladeshi nov. sp., Bangladesh. Emerging Infectious Diseases, 18, 1543-1545.

175. Santos MES, Ogando T, Fonseca BPV, Junior CEG, Barçante JMP. 2006. Ocorrência de enteroparasitos em crianças atendidas no programa de saúde da família de uma área de abrangência do município de Vespasiano, Minas Gerais, Brasil. Revista Eletrônica de Enfermagem, 8, 25-29.

176. Santos LP, Santos FLN, Soares NM. 2007. Prevalência de parasitoses intestinais em pacientes atendidos no hospital universitário Professor Edgar Santos, Salvador, Bahia. Revista de Patologia Tropical, 36, 237-246.

177. Santos SA, Merlini LS. 2010. Prevalência de enteroparasitoses na população do município de Maria Helena, Paraná. Ciência \& Saúde Coletiva, 15, 899-905.

178. Santos FLN, Gonçalves MS, Soares NM. 2011. Validation and utilization of PCR for differential diagnosis and prevalence determination of Entamoeba histolytica/Entamoeba dispar in Salvador city, Brazil. Brazilian Journal of Infectious Diseases, $15,119-125$.

179. Santos RV, Nunes JS, Camargo JASA, Rocha EMM, Fontes G, Camargo LMA. 2013. High occurrence of Entamoeba histolytica in the municipalities of Ariquemes and Monte Negro, State of Rondônia, Western Amazonia, Brazil. Revista do Intituto de Medicina Tropical de São Paulo, 55, 193-196.

180. Santos J, Duarte ARM, Gadotti G, Lima LM. 2014. Parasitoses intestinais em crianças de creche comunitária em Florianópolis, SC, Brasil. Revista de Patologia Tropical, 43, 332-340.

181. Santos HLC, Martins LAF, Peralta RHS, Peralta JM, Macedo HW. 2014. Frequency of amoebiasis and other intestinal parasitosis in a settlement in Ilhéus city, state of Bahia, Brazil. Revista da Sociedade Brasileira de Medicina Tropical, 47, 11-14.

182. Santos RV, Fontes G, Duarte IAC, Santos-Júnior JA, Rocha EMM. 2016. Identification of Entamoeba histolytica and E. dispar infection in Maceió, Alagoas State, northeast Brazil. Journal of Infection in Developing Countries, 10, 1146-1150.

183. Santos PHS, Barros RCS, Gomes KVG, Nery AA, Casotti CA. 2017. Prevalência de parasitoses intestinais e fatores associados em idosos. Revista Brasileira de Geriatria e Gerontologia, 20, 244-254.

184. Santos-Júnior GO, Silva MM, Santos FLN. 2006. Prevalência de enteroparasitoses em crianças do sertão baiano pelo método de sedimentação espontânea. Revista de Patologia Tropical, 35, 233-240.

185. Schnack FJ, Fontana LM, Barbosa PR, Silva LSM, Baillargeon CMM, Barichello T, Póvoa MM, Cavasini CE, Machado RLD. 2003. Enteropatógenos associados com diarreia infantil $(<5$ anos de idade) em amostras da população da área metropolitana de Criciúma, Santa Catarina, Brasil. Caderno de Saúde Pública, 19, 1205-1208.

186. Seixas MTL, Souza JN, Souza RP, Teixeira MCA, Soares NM. 2011. Avaliação da frequência de parasitos intestinais e do estado nutricional em escolares de uma área periurbana de salvador, Bahia, Brasil. Revista de Patologia Tropical, 40, 304-314.

187. Silva MCM, Monteiro CSP, Araújo BAV, Silva JV, Póvoa MM. 2005. Determinação da infeção por Entamoeba histolytica em residentes da área metropolitana de Belém, Pará, Brasil, utilizando o ensaio imunoenzimático (ELISA) para detecção de antígenos. Cadernos de Saúde Pública, 21, 969-973.
188. Silva MTN, Pontes A, Aragão P, Andrade J, Tavares-Neto J. 2005. Prevalência de parasitas intestinais em crianças, com baixos indicadores socio-econômicos, de Campina Grande (Paraíba). Revista Baiana de Saúde Pública, 29, 121-125.

189. Silva EF, Silva EB, Almeida KS, Sousa JJN, Freitas FL. 2009. Enteroparasitoses em crianças de áreas rurais do município de Coari, Amazonas, Brasil. Revista de Patologia Tropical, 38, 35-43.

190. Silva FS, Paulo ADC, Braga CMM, Almeida RJ, Galvão VP. 2010. Frequência de parasitos intestinais no municipio de Chapadinha, Maranhão, Brasil. Revista de Patologia Tropical, 39, 63-68.

191. Silva LP, Silva RMG. 2010. Ocorrência de enteroparasitos em centros de educação infantil no município de Patos de Minas, MG, Brasil. Biocience Journal, 26, 147-151.

192. Silva SRP, Arrosi N, Jesus RS, Reis RS, Rott MB. 2010. Enteroparasitoses em portadores de necessidades especiais prevalência em individuos atendidos em instituições do municipio de Porto Alegre-RS. Revista de Patologia Tropical, 39, 123-129.

193. Silva LP, Silva RMG, Fernandes NA, Oliveira JAA. 2011. Parasitos e/ou comensais em pacientes neoplásicos submetidos à quimioterapia. Bioscience Journal, 27, 170-177.

194. Silva EF, Silva VBC, Freitas FLC. 2012. Parasitoses intestinais em crianças residentes na comunidade ribeirinha São Francisco do Laranjal, município de Coari, estado do Amazonas, Brasil. Revista de Patologia Tropical, 41, 97-101.

195. Silva MTN, Santana JV, Bragagnoli G, Marinho AMN, Malagueño E. 2014. Prevalence of Entamoeba histolytical Entamoeba dispar in the city of Campina Grande, in northeastern Brazil. Revista do Instituto de Medicina Tropical de São Paulo, 56, 451-454.

196. Silva JSH, Silva DJ, Shaw JJ, Malheiros AF. 2018. Prevalência de enteroparasitos em moradores da cidade de Cáceres/MT. Revista Ibero Americana de Ciências Ambientais, 9, 154-164.

197. Silva PV, Maciel LS, Castro LS, Murat PG, Higa-Jr MG, Zerlotti PH, Motta-Castro ARC, Pontes ERJC, Dorval MEC. 2018. Enteroparasites in riverside settlements in the Pantanal wetlands ecosystem. Journal of Parasitology Research, 2018, e6839745.

198. Silva RSB, Malheiros AF, Santos DP, Shaw JJ, Araújo MSM, Moraes MFA, Campos WNL. 2019. Estudo de parasitoses intestinais em moradores de Corumbá, Mato Grosso do Sul, Brasil. Revista Ibero Americana de Ciências Ambientais, 10, 109-128.

199. Simões BS, Machado-Coelho GLL, Pena JL, Freitas SN. 2015. Condições ambientais e prevalência de infecção parasitária em indígenas Xukuru-Kariri, Caldas, Brasil. Revista Panamericana de Salud Publica, 38, 42-48.

200. Soares NM, Azevedo HC, Pacheco FTF, Souza JN, Del-Rei RP, Teixeira MCA, Santos FLN. 2019. A cross-sectional study of Entamoeba histolytica/dispar/moshkovskii complex in Salvador, Bahia, Brazil. Hindawi BioMed Research International, 2019, ID 7523670.

201. Sousa ACP, Costa LNG, Vieira JMS. 2018. Prevalência de enteroparasitas em individuos atendidos no Laboratório Municipal de Buriti dos Lopes, Piauí, Brasil. Revista Brasileira de Análises Clínicas, 50, 184-188.

202. Souza EA, Silva-Nunes M, Malafronte RS, Muniz PT, Cardoso MA, Ferreira MU. 2007. Prevalence and spatial distribution of intestinal parasitic infections in a rural Amazonian settlement, Acre state, Brazil. Caderno de Saúde Pública, 23, 427-434.

203. Souza MF, Pimentel-Neto M, Silva RM, Farias ACB, Guimarães MP. 2012. Gastrointestinal parasites of sheep, 
municipality of Lajes Rio Grande do Norte, Brazil. Revista Brasileira de Parasitologia Veterinária, 21, 71-73.

204. Souza LS, Guilherme E, Andrade AMF, Santos FGA. 2019. Occurrence o fendo and hemoparasites in Sporophila caerulescens captured in the eastern region of the state of Acre, Brazil. Ciência Rural, 49, e20180811.

205. Stensvold CR, Lebbad M, Clark CG. 2010. Genetic characterisation of uninucleated cyst-producing Entamoeba spp. from ruminants. International Journal for Parasitology, 40, 775-778.

206. Stensvold CR, Lebbad M, Victory EL, Verweij JJ, Tannich E, Alfellani M, Legarraga P, Clark CG. 2011. Increased sampling reveals novel lineages of Entamoeba: consequences of genetic diversity and host specificity for taxonomy and molecular detection. Protist, 162, 525-541.

207. Takizawa MGMH, Falavigna DLM, Gomes ML. 2009. Enteroparasitosis and their ethnographic relationship to food handlers in a tourist and economic center in Paraná, southern Brazil. Revista Instituto de Medicina Tropical de São Paulo, 51, 31-35.

208. Tashima NT, Simões MJS. 2004. Enteroparasitic occurrence in fecal samples analyzed at the University of western São PauloUNOESTE clinical laboratory, Presidente Prudente São Paulo state, Brazil. Revista do Instituto de Medicina Tropical de São Paulo, 46, 243-248.

209. Tashima NT, Simões MJS, Leite CQF, Fluminhan A, Nogueira MA, Malaspina AC. 2009. Classic and molecular study of Giardia duodenalis in children from a daycare center in the region of Presidente Prudente, São Paulo, Brazil. Revista do Instituto de Medicina Tropical de São Paulo, 51, 19-24.

210. Tavares-Dias M, Grandini AA. 1999. Prevalencia e aspectos epidemiológicos de enteroparasitoses na população de São José da Bela Vista, São Paulo. Revista da Sociedade Brasileira de Medicina Tropical, 32, 63-65.

211. Turkeltaub JA, McCarty TR, Hotez PJ. 2015. The intestinal protozoa: emerging impacto $\mathrm{n}$ global health and development. Current Opinion in Gastroenterology, 31, 38-44.

212. Uchoa CMA, Lobo AGB, Bastos OMP, Matos AD. 2001. Parasitoses intestinais: prevalência em creches comunitárias da cidade de Niterói, Rio de Janeiro-Brasil. Revista do Instituto Adolfo Lutz, 60, 97-101.

213. Uchoa CMA, Albuquerque MC, Carvalho FM, Falcão AO, Silva P, Bastos OMP. 2009. Parasitismo intestinal em crianças e funcionários de creches comunitárias na cidade de NiteróiRJ, Brasil. Revista de Patologia Tropical, 38, 267-278.

214. Valença-Barbosa C, Batista RJ, Igreja RP, d'Avila-Levy CM, Macedo HW, Santos HLC. 2017. Distribution of Blastocystis subtypes isolated from humans from an urban community in Rio de Janeiro, Brazil. Parasites \& Vectors, 10, 1-9.

215. Valverde JG, Gomes-Slva A, Moreira CJC, Souza DL, Jaeger LH, Martins PP, Meneses VF, Boia MN, Carvalho-Costa FA. 2011. Prevalence and epidemiology of intestinal parasitism, as revealed by three distinct techniques in an endemic area in the Brazilian Amazon. Annals of Tropical Medicine and Parasitology, 105, 413-424.

216. Ximénez C, Morán P, Rojas L, Valadez A, Gómez A. 2009. Reassessment of the epidemiology of amebiasis: state of the art. Infection, Genetics and Evolution, 9, 1023-1032.

217. Zanetti AS, Silva Junior IC, Barros LF, Domínguez OAE, Lima GS, Silva AS, Danelichen OS, Silva SL, Moreira LM, Shaw JJ, Malheiros AF. 2019. Parasitas intestinais em cães provenientes dos biomas do nordeste brasileiro: aspecto zoonótico e ambiental. Revista Ibero-Americana de Ciências Ambientais, 10, 42-51.

218. Zanotto M, Cavagnolli NI, Breda JC, Spada PKWDS, Bortolini GV, Rodrigues AD. 2018. Prevalence of intestinal parasites and socioeconomic evaluation of a country town in the Serra Gaucha región, Rio Grande do Sul, Brazil. Revista de Patologia Tropical, 47, 19-30.

219. Zenazokenae LE, Terças-Trettel ACP, Nascimento VF, Hattori TY, Atanaka M, Lemos ERS, Boia MN. 2019. Prevalence of enteroparasitosis in the indigenous communit y of Mato Grosso, Brazil: a look into the sanitation and ethno-development. Saúde e Pesquisa, 12, 253-264.

220. Zhang Q, Liu K, Wang C, Luo J, Lu J, He H. 2019. Molecular characterization of Entamoeba spp. in wild Taihangshan macaques (Macaca mulatta tcheliensis) in China. Acta Parasitologica, 64, 228-231.

Cite this article as: Zanetti AS, Malheiros AF, de Matos TA, dos Santos C, Battaglini PF, Moreira LM, Lemos LMS, Castrillon SKI, Cortela DCB, Ignotti E \& Espinosa OA. 2021. Diversity, geographical distribution, and prevalence of Entamoeba spp. in Brazil: a systematic review and meta-analysis. Parasite 28, 17.

\section{PARASTE}

An international open-access, peer-reviewed, online journal publishing high quality papers on all aspects of human and animal parasitology

Reviews, articles and short notes may be submitted. Fields include, but are not limited to: general, medical and veterinary parasitology; morphology, including ultrastructure; parasite systematics, including entomology, acarology, helminthology and protistology, and molecular analyses; molecular biology and biochemistry; immunology of parasitic diseases; host-parasite relationships; ecology and life history of parasites; epidemiology; therapeutics; new diagnostic tools.

All papers in Parasite are published in English. Manuscripts should have a broad interest and must not have been published or submitted elsewhere. No limit is imposed on the length of manuscripts.

Parasite (open-access) continues Parasite (print and online editions, 1994-2012) and Annales de Parasitologie Humaine et Comparée (1923-1993) and is the official journal of the Société Française de Parasitologie. 